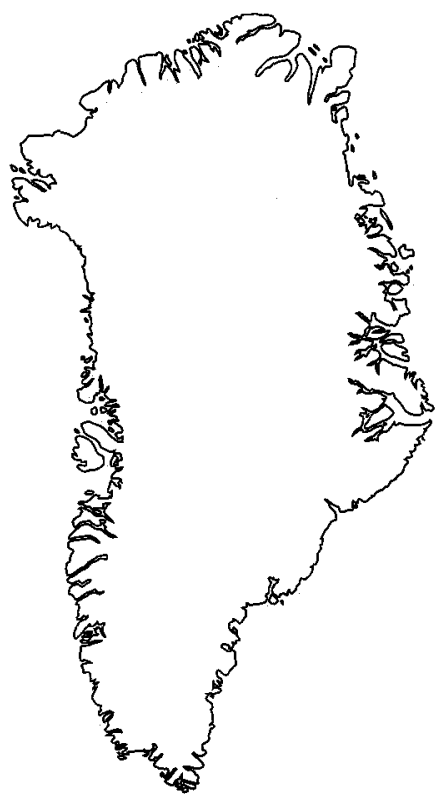

\title{
Stratigraphy and depositional evolution of the Upper Palaeozoic sedimentary succession in eastern Peary Land, North Greenland
}

\author{
Lars Stemmerik, Eckart Håkansson, Lena Madsen, \\ Inger Nilsson, Stefan Piasecki ${ }^{1}$, Sylvie Pinard ${ }^{2}$ \\ and Jan A. Rasmussen
}

\begin{abstract}
The Upper Palaeozoic Foldedal and Kim Fjelde formations in eastern Peary Land are redefined on the basis of new biostratigraphic data, including fusulinids, conodonts, palynomorps and small foraminifera. The Foldedal Formation in its new definition includes all late Moscovian to Gzelian deposits in the region. It is separated by a major hiatus from the redefined Kim Fjelde Formation which includes mid-Permian (late Artinskian - Kungurian) carbonates and chert deposits. The Upper Carboniferous succession is dominated by cyclically interbedded siliciclastics and carbonates with minor tabular build-ups. The mid and Upper Permian succession consists of cool-water carbonates, spiculitic chert and shales.
\end{abstract}

L. S., S. P. ${ }^{I} \&$ J. A. R., Geological Survey of Denmark and Greenland, Thoravej 8, DK2400 Copenhagen NV, Denmark.

E. H. \& L. M., Geological Institute, University of Copenhagen, $\emptyset$ ster Voldgade 10, DK1350 Copenhagen K, Denmark.

I. N., Saga Petroleum a.s., Postboks 1134, N-9400 Harstad, Norway.

S. P. ${ }^{2}, 7146-119$ th Street N.W., Edmonton T6G IV6, Canada (formerly of the Geological Survey of Canada).

In eastern Peary Land, the marine Upper Palaeozoic deposits of the Wandel Sea Basin have been included in the upper Moscovian to Upper Carboniferous Foldedal Formation of mixed carbonates and siliciclastics, the Upper Carboniferous to (?) Kungurian carbonate-dominated Kim Fjelde Formation and the shale-dominated, mid to Upper Permian Midnatfjeld Formation (Håkansson, 1979; Stemmerik \& Håkansson, 1989). Originally it was suggested these formations formed a continuous sedimentary succession of mid-Carboniferous to Late Permian age (Håkansson, 1979; Håkansson \& Stemmerik, 1984; Stemmerik \& Håkansson, 1989, 1991). However, field work in the area in 1991 proved thepresence of a major subaerial exposure surface within the Kim Fjelde Formation in the southern part of the outcrop area. Later, field work in Amdrup Land and Holm Land further to the east has shown that this exposure event is of regional significance (Stemmerik \& Elvebakk, 1994). Biostratigraphic data indicate that the exposure surface represents a major hia- tus spanning most of the Early Permian, and accordingly, the originally proposed lithostratigraphic scheme has to be revised.

This paper revises the lithostratigraphy of the Upper Palaeozoic deposits in eastern Peary Land in accordance with new sedimentological and sequence stratigraphic information, and provides new biostratigraphic data from the succession (Figs 1,2). Age dating is based on fusulinids in the Carboniferous part of the succession with some additional data from conodonts, and on conodonts, small foraminifera and palynomorphs in the Permian part of the succession. The boundary between the Foldedal Formation and Kim Fjelde Formation is an erosional unconformity while the boundary between the Kim Fjelde Formation and the Midnatfjeld Formation is a major flood surface.

The Foldedal Formation is redefined to include a succession of mixed siliciclastics and shallow shelf carbonates of late Moscovian to Gzelian (?earliest Asselian) 


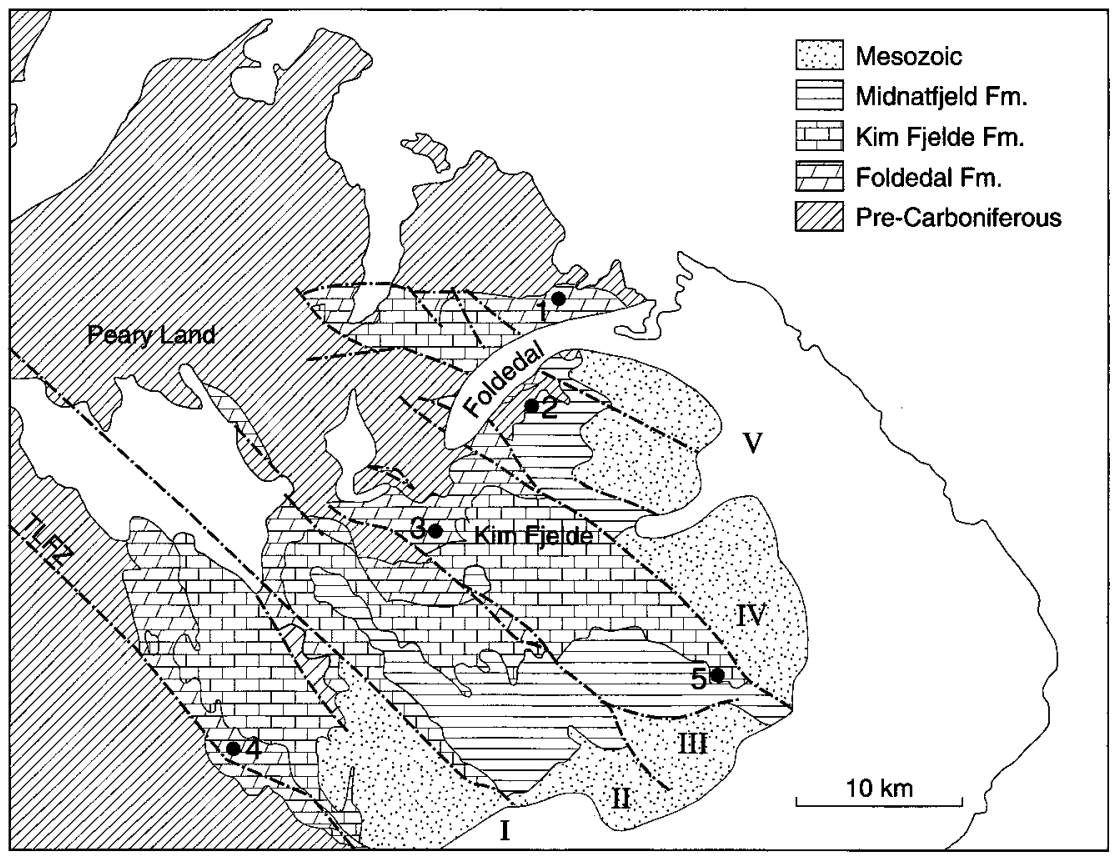

Fig. 1. Geological map of eastern Peary Land showing distribution of Upper Palaeozoic formations and location of measured sections (1-5). I to $\mathrm{V}$ are major fault blocks within the Trolle Land Fault System. TLFZ: Trolle Land Fault Zone.

age. It includes the lower part of the Kim Fjelde Formation as it was defined by Håkansson (1979) and Stemmerik \& Håkansson (1989). The Kim Fjelde Formation is defined to include a succession of normal marine shallow to deeper shelf carbonates of late Artinskian to Kungurian age. The Midnatfjeld Formation is composed of two shallowing upward successions of Kazanian age.

\section{Biostratigraphy}

The Carboniferous part of the succession has been dated by fusulinids, while the Permian sediments have been dated by a combination of conodonts, small foraminifera and palynomorphs. The fusulinid assemblages identified in the Moscovian-Gzelian succession are comparable to assemblages previously described from the Wandel Sea Basin (Petryk, 1977; Nilsson et al., 1991; Nilsson, 1994; Stemmerik et al., 1995a; Dunbar et al., 1962), and they can be correlated to the fusulinid zones in the Russian stratotype area.

Biostratigraphic zonation is less firmly established in the late Artinskian and younger Permian sediments due to lack of fusulinids in the Arctic region. Conodonts, smallforaminifera and palynomorphs have been compared to local zonations in the Sverdrup Basin, Svalbard and the Barents Sea to establish the best possible correlation.

\section{Upper Carboniferous}

Fusulinids. In the lower part of the Foldedal Formation in northern Foldedal (sections 1 and 3 in Fig. 2) a fusulinid assemblage characterised by Beedeina aff. B. paradistenta, Parawedekindellina sp., Fusulinella eopulchra, F. pulchra, Pseudostafella sp., Ozawinella spp., Eostafella sp., Schubertella sp. and Pseudoendothyra sp. occurs. This assemblage shows close similarities with the late Moscovian Wedekindellina assemblage of Dunbar et al. (1962) and it is regarded as being of the same age. An assemblage composed of Protriticites spp., Fusulinella aff. F. eupulchra and Quasifusulinoides fusiformis is regarded as slightly younger and has been assigned to the latest Moscovian-?early Kasimovian. Upper Kasimovian strata are characterised by a Rauserites ex. gr. simplex assemblage with $R$. simplex, $R$. aff. $R$. irregularis, Pseudofusulinella usvae and Schubertella transitoria. This fauna can be correlated to the $R$. ex. gr. simplex assemblage of Nilsson (1994). Sediments belonging to the early-middle Gzelian Rauserites ex. gr. rossicus assemblage occur in the upper part of the Foldedal Formation in section 1 of northern Foldedal (Fig. 2). This assemblage is characterised by $R$. ex.gr. rossicus, Rugosofusulina aff. $R$. prisca, $R$. aff. $R$. moderata, $R$. aff. $R$. eliptica, Daixina? sp. and $S c h u b e r t e l l a$ transitoria. The youngest fusulinid-bearing sediments so far recognised in eastern Peary Land are characterised by a fauna including Daixina ex. gr. navicullaeformis of late Gzelian age.

Two conodont assemblages have been observed in the Foldedal Formation. The oldest, which is a monospecific assemblage of Idiognathodus incurvus, was found in limestones $5 \mathrm{~m}$ above the Kap Bunch Member at locality 3 


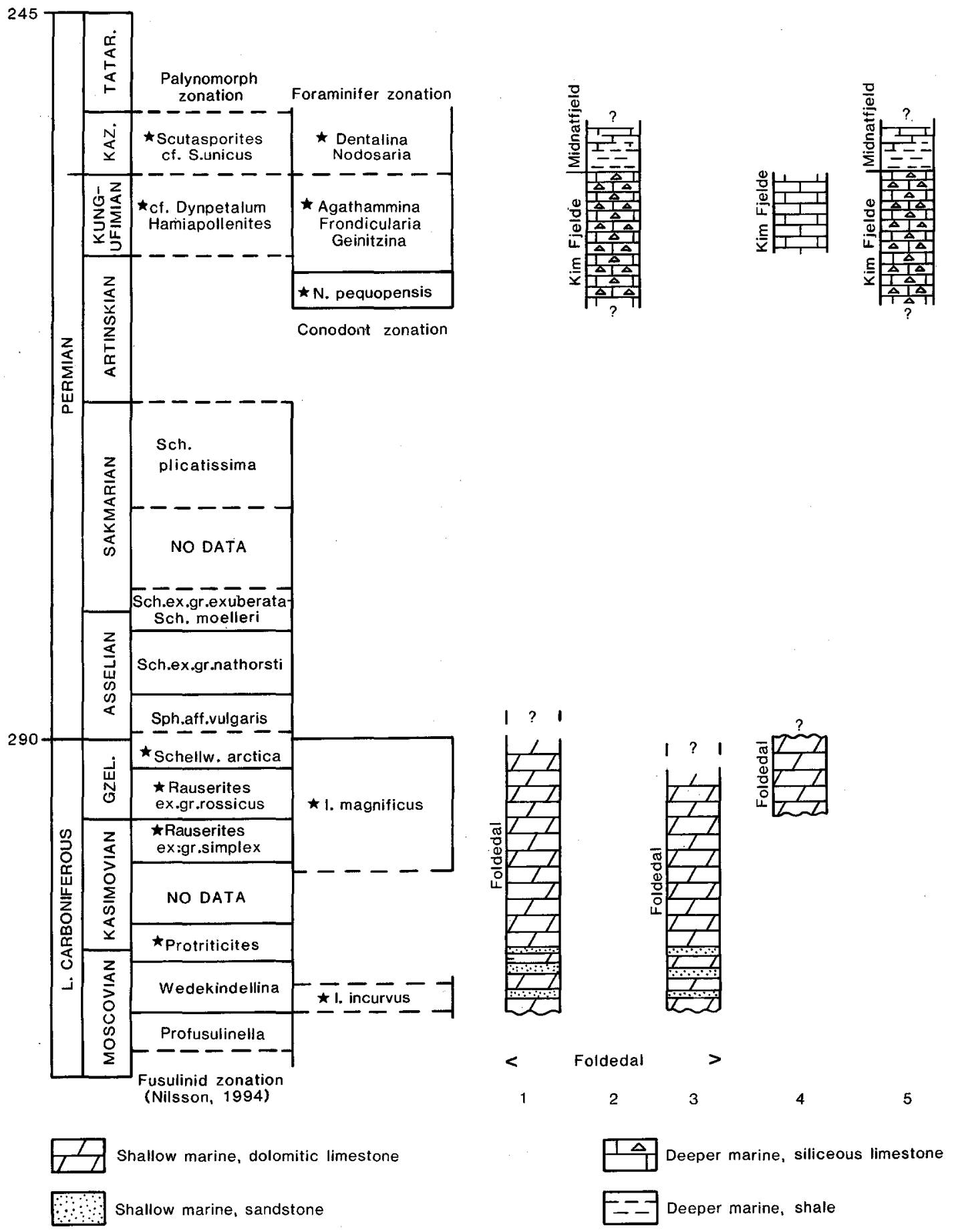

Fig. 2. Correlation of Upper Palaeozoic sediments in eastern Peary Land. Locations of sections 1 to 5 are given in Fig. 1. 


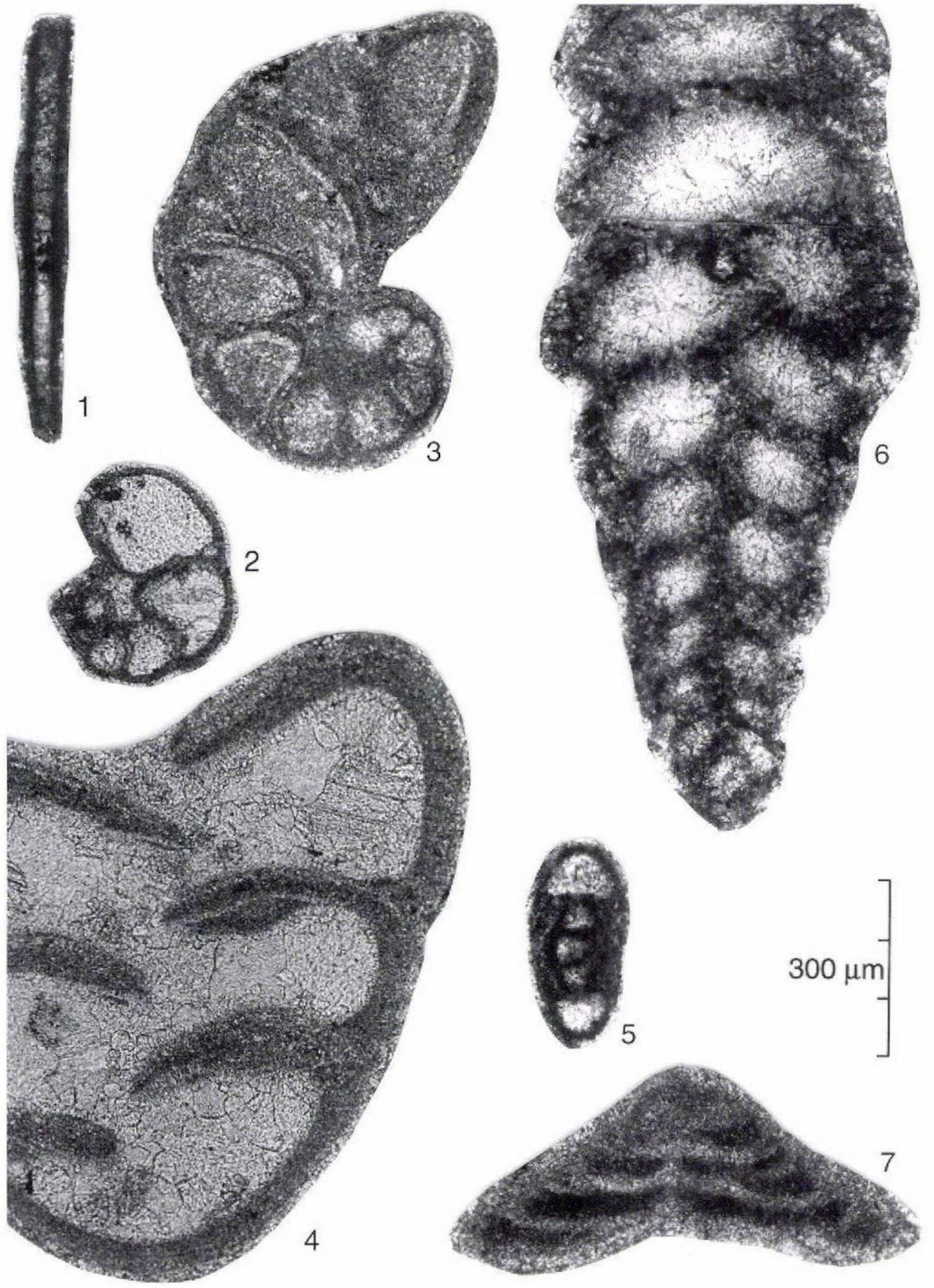

Fig. 3. Small foraminifera from the Kim Fjelde Formation. Fig. 3.1: Earlandia ex.group elegans. Longitudinal section. MGUH 23642 from GGU 334521 A. Fig. 3.2: Globivalvulina sp. 1. Equatorial oblique section. MGUH 23643 from GGU 334647B. Fig. 3.3: Globivalvulina sp. 2. Equatorial section. MGUH 23644 from GGU 334513B. Fig. 3.4: Globivalvulina sp. 2. Para-axial section. MGUH 23645 from GGU 334513A. Fig. 3.5: Neoendothyra? sp. Para-axial section slightly oblique. MGUH 23646 from GGU 334521 A. Fig. 3.6: Deckerella? sp. Longitudinal frontal section. MGUH 23647 from GGU 334521A. Fig. 3.7: Tetrataxis sp. Longitudinal oblique section. MGUH 23648 from GGU 334648A. 

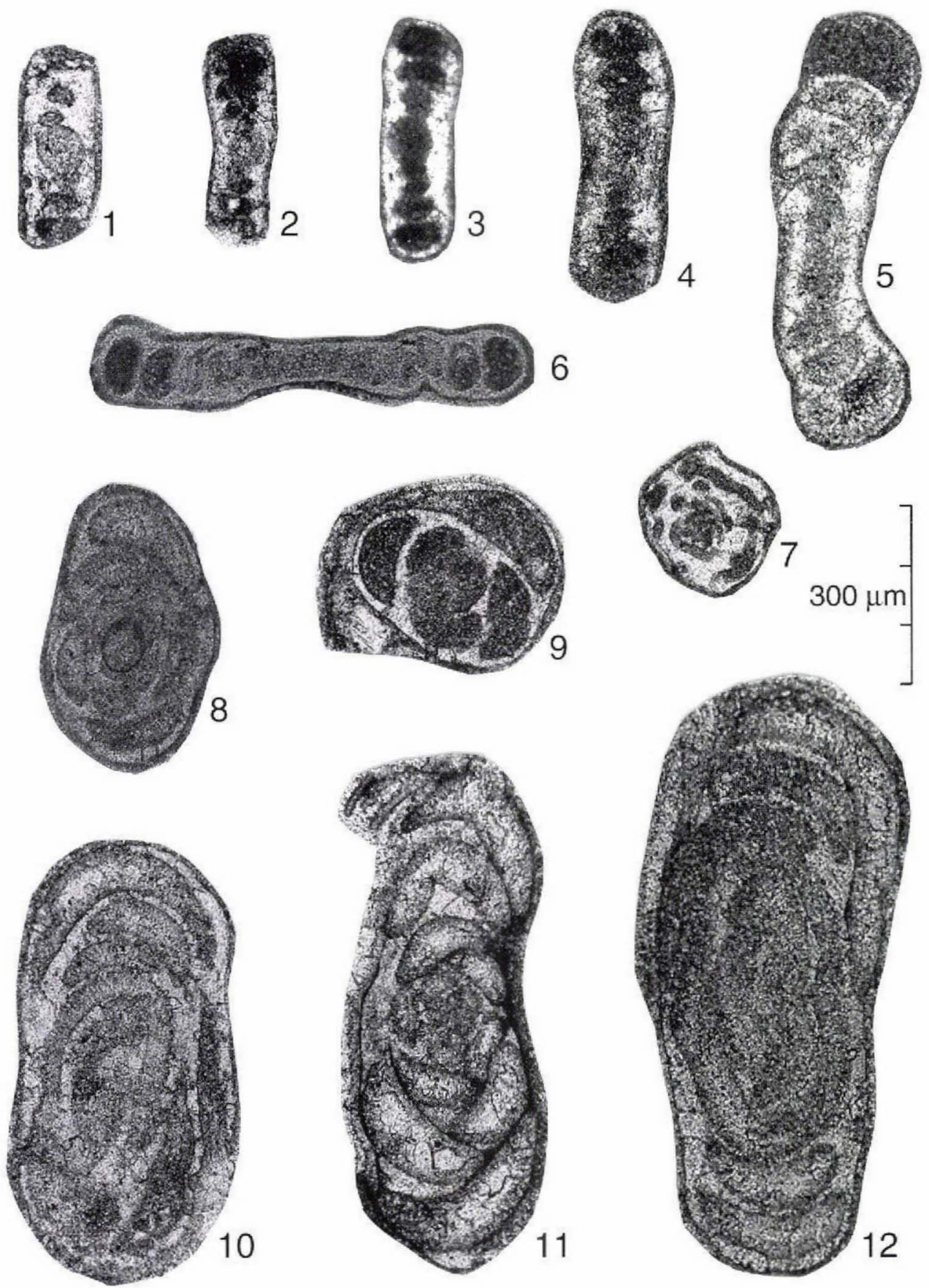

Fig. 4. Small foraminifera from the Kim Fjelde Formation. Figs 4.1-4.5: 'Neohemigordius' aff. saranensis (Baryshnikov in Baryshnikov, Zolotova \& Koscheleva, 1982). Fig. 4.1: Axial section. MGUH 23649 from GGU 334648B. Fig. 4.2: Para-axial section. MGUH 23650 from GGU 334648B. Fig. 4.3: Axial section. MGUH 23651 from GGU 334648A. Fig. 4.4: Para-axial section. MGUH 23652 from GGU 334648B. Fig. 4.5: Para-axial section. MGUH 23453 from GGU 334648B. Fig. 4.6: 'Cornuspira sp. Para-axial section. MGUH 23654 from GGU 334657. Fig 4.7: 'Glomospira' sp. MGUH 23655 from GGU 334646A. Figs 4.8-4.12: 'Agathammina' mandulaensis? Xia \& Zhang (1984). Fig. 4.8: Transversal oblique section. MGUH 23656 from GGU 334646. Fig. 4.9: Transversal section. MGUH 23657 from GGU 334646B. Fig. 4. 10: Oblique longitudinal section.MGUH 23658 from GGU 334646B. Fig. 4.11: Oblique longitudinal section. MGUH 23659 from GGU 334646B. Fig. 4.12: Longitudinal para-axial section. MGUH 23660 from GGU 334646 B. 

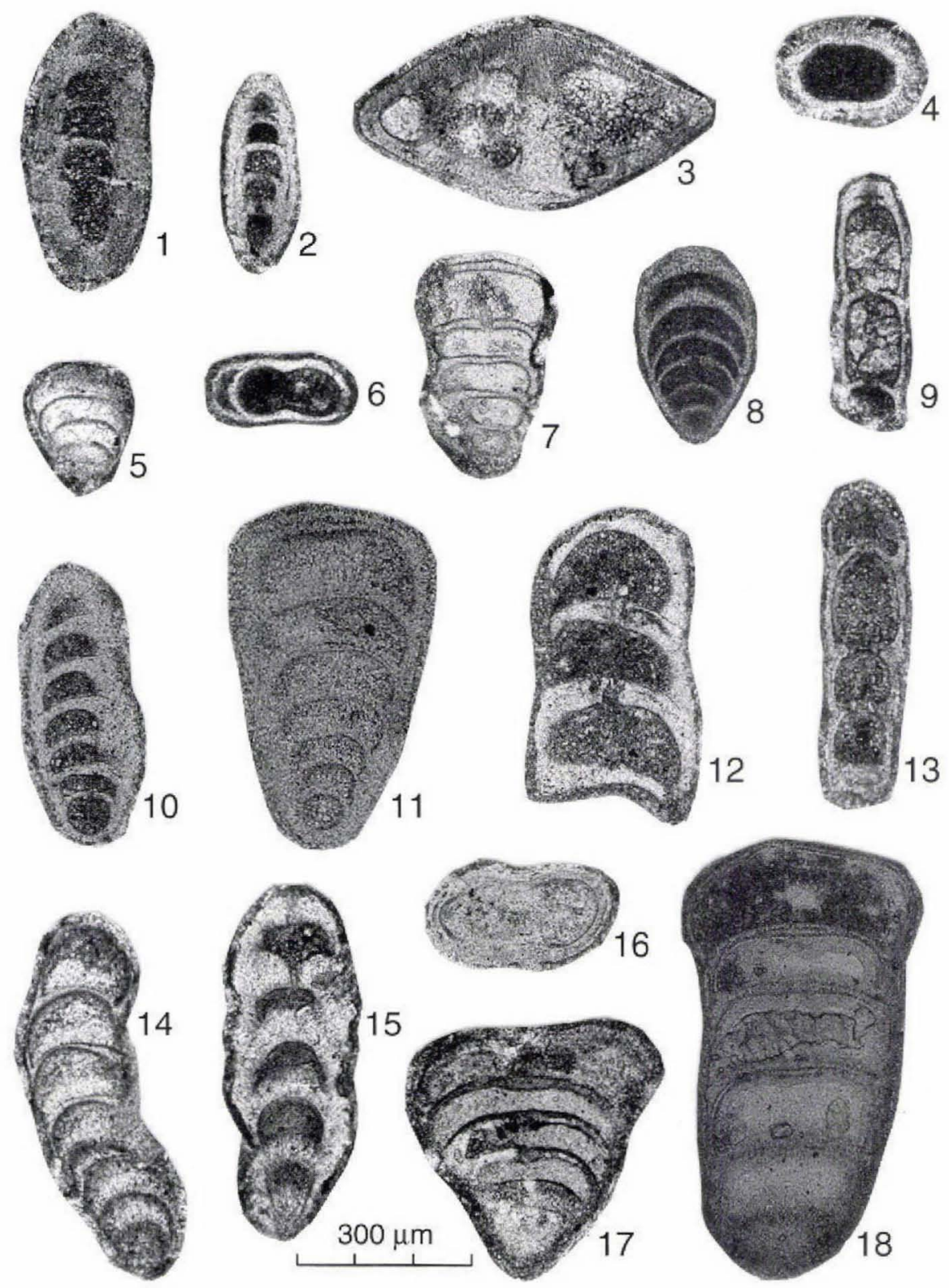

Fig. 5. Small foraminifera from the Kim Fjelde Formation. Figs 5.1-5.2: 'Langella'? sp. Fig. 5.1: Oblique section. MGUH 23661 from GGU 334646B. Fig. 5.2: Oblique section. MGUH 23662 from GGU 334646A. Fig. 5.3: Pachyphloia? sp. Transversal section. MGUH 23663 from GGU 334657A. Fig. 5.4: Ornamented frondicularid. Transversal section. MGUH 23664 from GGU $334646 B$. Figs 5.5-5.7: 'Geinitzina' sp. 1. Fig. 5.5: Frontal oblique section. MGUH 23665 from GGU 334513B. Fig. 5.6: Transversal section. MGUH 23666 from GGU 334646A. Fig. 5.7: Longitudinal frontal section. MGUH 23667 from GGU 334523B. Fig. 5.8: 'Frondicularia' sp. 1. MGUH 23668 from GGU 334646. Fig. 5.9: Tezaquina? sp. Axial section. MGUH 23669 from GGU 334521A. Figs 5.10-5.11: 'Geinitzina' sp. 2. Fig. 5.10: Longitudinal oblique section. MGUH 23670 from GGU 334646A. Fig. 5.11: Longitudinal oblique section. MGUH 23671 from GGU 334646B. Fig. 5.12: Undetermined Genus A. Longitudinal oblique section. MGUH 23672 from GGU 334646B. Fig. 5.13: 'Nodosaria' sp. Longitudinal section. MGUH 23673 from GGU 334657B. Fig. 14. 'Lenticulina' sp. Longitudinal section. MGUH 23674 from GGU 334646A. Fig. 15: 'Frondicularia' sp. (cf. Gerkeina sp. nov. in Sosipatrova, 1967 , pl. 12, fig. 33) MGUH 23675 from GGU 334523B. Fig. 16: 'Geinitzina' sp. 3?. Transversal section. MGUH 23676 from GGU $334646 \mathrm{~B}$. Fig. 17: Pachyphloia? sp. Longitudinal frontal section. MGUH 23677 from GGU 334509A. Fig. 18: 'Geinitzina 'sp. 3 (cf. Geinitzina gigantea Miklukho-Maklai sensu Sosipatrova, 1967, pl. 12, fig. 40). Longitudinal frontal non-axial section. MGUH 23678 from GGU 334657. 

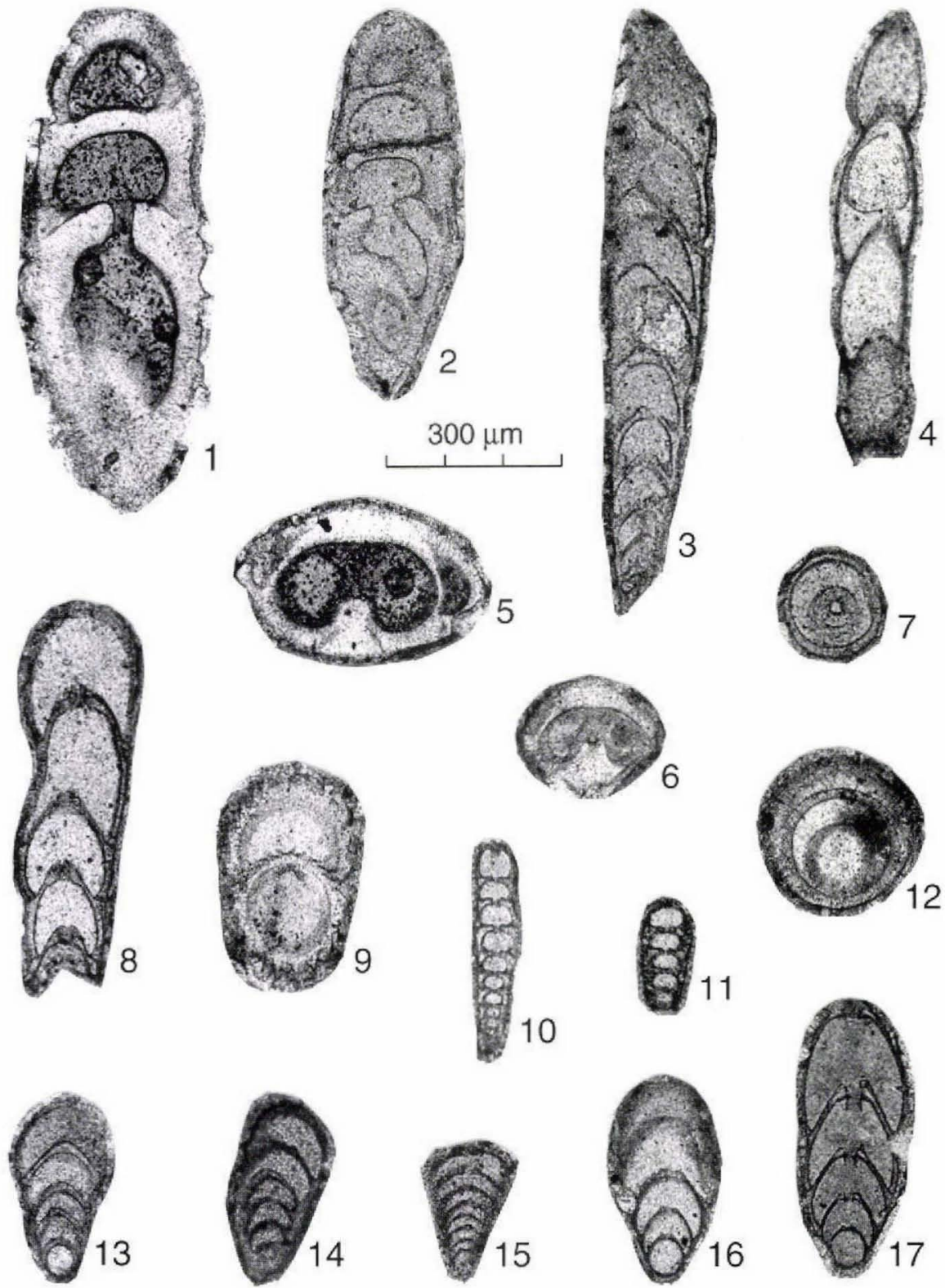

Fig. 6. Small foraminifera from the Midnatsfjeld Formation. Figs 6.1-6.2: Undetermined Genus B. Fig. 6.1: Oblique section. MGUH 23679 from GGU 334506A. Fig. 6.2: Oblique section. MGUH 23680 from GGU 334511B. Fig. 6.3: 'Frondicularia' sp. 2. Parafrontal section? MGUH 23681 from GGU 334506A. Fig. 6.4: 'Dentalina' siliquaformis sensuSosipatrova (1967). Axial section. MGUH 23682 from GGU 334505A. Figs 6.5-6.6: 'Frondicularia' sp. 2?. Fig. 6.5: Transversal section. MGUH 23683 from GGU 334506A. Fig. 5.6: Transversal section slightly oblique showing partly the opening. MGUH 23684 from GGU 334511A. Fig. 6.7: ?'Dentalina' siliquaformis sensu Sosipatrova (1967). Transversal section passing by the opening. MGUH 23685 from GGU 334506 A. Fig. 6.8: 'Frondicularia' sp. 2?. Lateral axial section? MGUH 23686 from GGU 334506B. Fig. 6.9: Echinodosaria sp. Transversal oblique section. MGUH 23687 from GGU 334511A. Figs 6.10-6.11: Nodosarid? sp. or lateral section of 'Frondicularia' sp. 4. Fig. 6.10: Longitudinal section. MGUH 23688 from GGU 334511 A. Fig. 6.11: Longitudinal section. MGUH 23689 from GGU 334505B. Fig. 6.12: 'Pseudonodosaria'? sp. (=Rectoglandulina of most authors). Oblique section. MGUH 23690 from GGU 334506A. Figs 6.13-6.14: 'Frondicularia' sp. 3. Fig. 6.13: Para-frontal section. MGUH 23691 from GGU 334506 A. Fig. 6.14: Para-frontal section. MGUH 23692 from GGU 334506. Fig. 6.15: 'Frondicularia' sp. 4. Frontal section. MGUH 23693 from GGU 334505B. Figs 6.16-6.17: 'Pseudonodosaria' sp. (=Rectoglandulina of most authors). Axial section. MGUH 23694 from GGU 334511. Fig. 6.17: Axial section. MGUH 23695 from GGU 334511A. 
(Fig. 1). The species characterises the Atokan (midMoscovian) of the southwestern United States (Dunn, 1966) and the 'Aegiranum Marine Band' (Westphalian C) of the Netherlands, Belgium and England (van den Boogaard \& Bless, 1985).

A younger conodont assemblage comprising Idiognathodus magnificus and Hindeodus minutus was identified within the upper part of the Foldedal Formation near locality 4 (Fig. 1). I. magnificus has been reported from Missourian and Virgilian strata of the United States(Grayson et al., 1990, with earlier references) and the Kasimovian and Gzelian of the Dneprovsko-Donetzkaya depression (Kozitskaya, 1983; reported as Idiognathodus lobulatus, I. toretcianus, I. saggitalis, Streptognathodus alekseevi, S. firmus and $S$. luganicus). H. minutus is long-ranging and has been described from the Kasimovian (Baesemann, 1973) to the late Artinskian (Nakrem, 1991).

\section{Permian}

Conodonts. In the lower part of the Kim Fjelde Formation, as defined in this paper, a conodont assemblage occurs characterised by Neostreptognathodus pequopensis and Ellisonia conflexa. $N$. pequopensis is regarded as a late Artinskian index fossil in the Arctic region. It occurs in upper Artinskian strata of the Sverdrup Basin (Beauchamp et al., 1989; Beauchamp \& Henderson, 1994). N. pequopensis also occurs in the upper Artinskian, lower part of the Kapp Starostin Formation and upper part of the Hambergfjellet Formation in Svalbard (Nakrem, 1991; Nakrem et al., 1992). In these areas it co-occurs with $S$. jenkinsi; this fusulinid has so far not been recorded from Greenland. Ellisonia conflexa is a long ranging species which disappears in the latest Artinskian.

Small foraminifera. Two different assemblages of small foraminifera have been identified in the Permian part of the succession (Figs 3, 4, 5, 6). The oldest assemblage is confined to the Kim Fjelde Formation, and contains 'Agathammina' mandulaensis?, 'Cornuspira'sp., Deckerella? sp., Earlandia ex.gr. elegans, 'Frondicularia' sp. 1, Frondicularia sp., Geinitzina sp. 1, Geinitzina sp. 2, Geinitzina sp. 3, Globivalvulina sp. 1, Globivalvulina sp. 2, 'Glomospira' sp., 'Langella' sp., 'Lenticulina' sp., Neoendothyra? sp., 'Neohemigordius' aff. saranensis, 'Nodosaria' sp., 'Pachypholia'? sp., Tetrataxis sp. and Tezaquina sp. This fauna resembles late Artinskian - Kungurian foraminifer assemblages described from the lower part of the Kapp Starostin Formation on Spitsbergen (Sosipatrova, 1967). 'Neohemigordius' aff. $N$. saranensis was originally described from the Sarininian, uppermost Artinskian of the pre-Ural (Baryshnikov et al., 1982). In Russia and the Sverdrup Basin of Arctic Canada, Frondicularia has its first appearance in the Artinskian together with forms like Geinitzina and Pachyphloia. Agathammina has its acme in beds of Kungurian-Kazanian age (Pronina, 1990). It is restricted to post-Artinskian beds in the Sverdrup Basin while Agathammina ?mandulaensis occurs in proposed Artinskian-Kungurian strata in Mongolia (Xia \& Zhang, 1984). Based on these comparisons it is suggested that the assemblage is of late Artinskian - Kungurian age (Fig. 2).

An assemblage dominated by 'Dentalina' siliquaformis, Echinodosaria sp., 'Frondicularia' sp. 2, 'Frondicularia' sp. 3, 'Frondicularia' sp. 4, undetermined Genus B (Fig. 6.1), Nodosarid? sp. and 'Pseudonodosaria' sp. occurs in the Midnatfjeld Formation. This assemblage resembles the fauna described from the late Kungurian?Kazanian, middle and upper parts of the Kapp Starostin Formation on Spitsbergen (Sosipatrova, 1967) and the Kazanian Degerböls and Trold Fiord formations in the Sverdrup Basin. This points towards a late Kungurian to Kazanian age for this assemblage.

Palynomorphs. Two distinctive palynomorph assemblages are identified in the Permian succession (Figs 7, 8). In the basal part of the Kim Fjelde Formation on the southernmost fault block in Peary Land (section 4 in Fig. 2), the flora is dominated by terrestrial palynomorphs with rare acritachs. The flora contains both bisaccate pollen and spores but stratigraphically significant species are rare (Fig. 7). The presence of Maculatasporites sp. (cf. Reticulina bilateralis) and Hamiapollenites sp. in combination with the absence of any Taeniaesporites, Lunatisporites, Scutasporites and Lueckiisporites and the absence of the Unellium-Starostina acritarch assemblage suggest that the flora has affinities to the Dynpetalum sp. Hamiapollenites bullaeformis assemblage from the Finnmark Platform (Mangerud, 1994). This assemblage by comparison to the Sverdrup Basin is considered as Kungurian-Ufimian in age, and a similar age is suggested for the North Greenland flora.

In the Midnatfjeld Formation, the flora is dominated by acritachs such as Unellium starostina, U. permica and Starostina reinodderisis (Fig. 8). The terrestrial sporomorphs comprise Vittatina, Scutasporites sp., Krauselisporites sp. and a variety of trilete spores. The Midnatfjeld Formation assemblage resembles the flora found in the lower part of the Scutasporites sp. cf. S. unicus - Lunatisporites sp. Concurrent Range Zone from the Finnmark Platform (Mangerud, 1994), the flora in the Unellium zone and the Krauselisporites sp. assemblage of Spitsbergen (Konieczny, 1987; Mangerud \& Konieczny, 1993). The abundance of Unellium sp. and Starostina spp. and the occurrence of Scutasporites cf. S. unicus suggest a Kazanian age for this assemblage. 

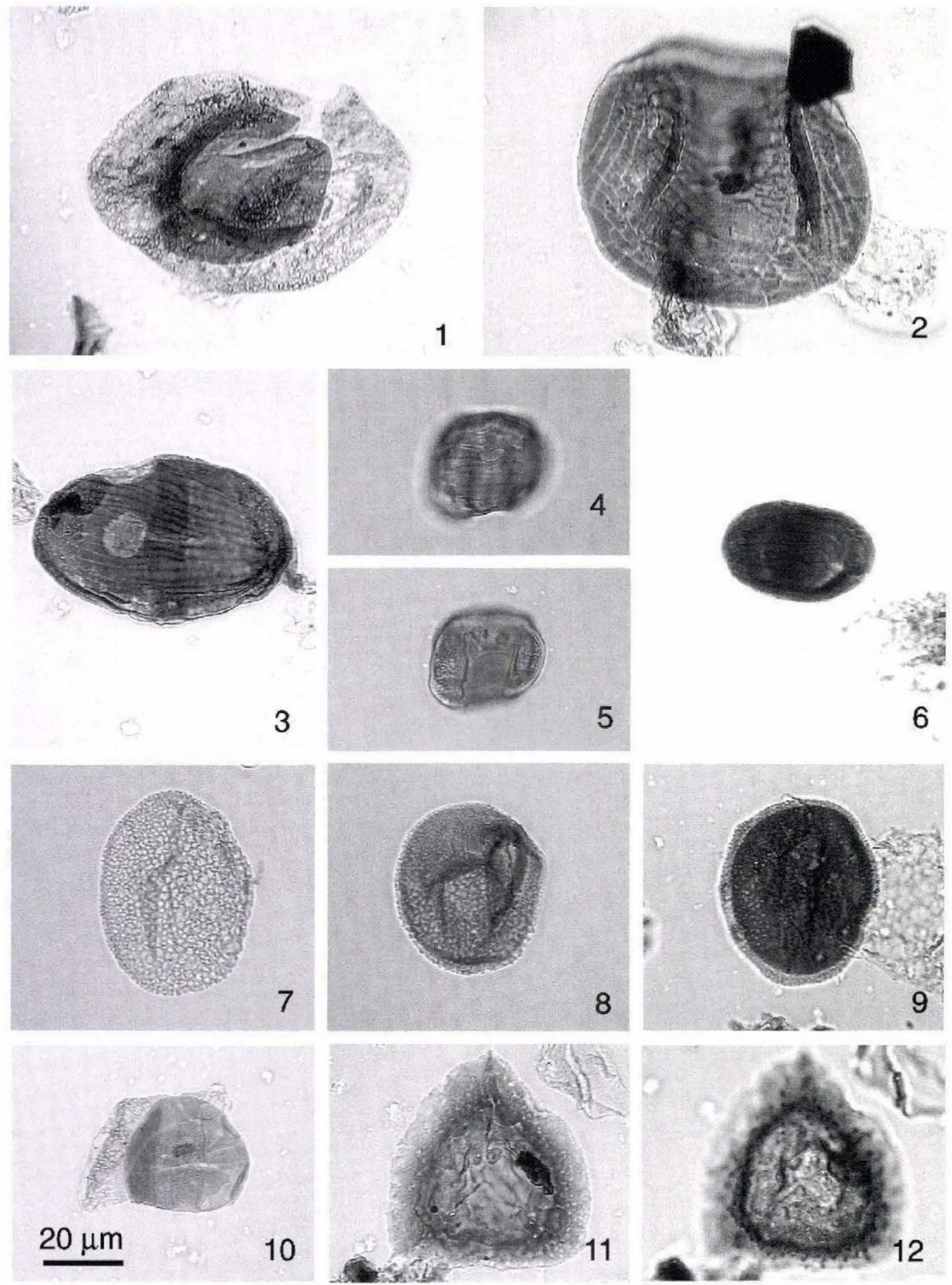

Fig. 7. Palynomorphs from the Kim Fjelde Formation. Fig. 7.1: Potonieisporites sp., MGUH 23696 from GGU 334600. Fig. 7.2: Vittatina striata, MGUH 23697 from GGU 334644. Fig. 7.3: Vittatina costabilis, MGUH 23698 from GGU 334603. Fig. 7.4 and 7.5: Vittatina saccifer, MGUH 23699-23700 from GGU 334603. Fig. 7.6: Vittatina subsaccata, MGUH 23701 from GGU 334603. Figs 7.7-7.9: Maculatasporites sp. (aff. 'Reticulina bilateralis'), MGUH 23702-23704 from GGU 334600 and 334603 . Fig. 7.10: Hamiapollenites sp., MGUH 23705 from GGU 334603. Figs 7.11-7.12: Kraeuselisporites spinosus, MGUH 23706-23707 from GGU 334600 . NB: Figs 7.1 and 7.2 are 1.3 times larger than figs $7.3-7.12$ and the 20 micron bar. 
54
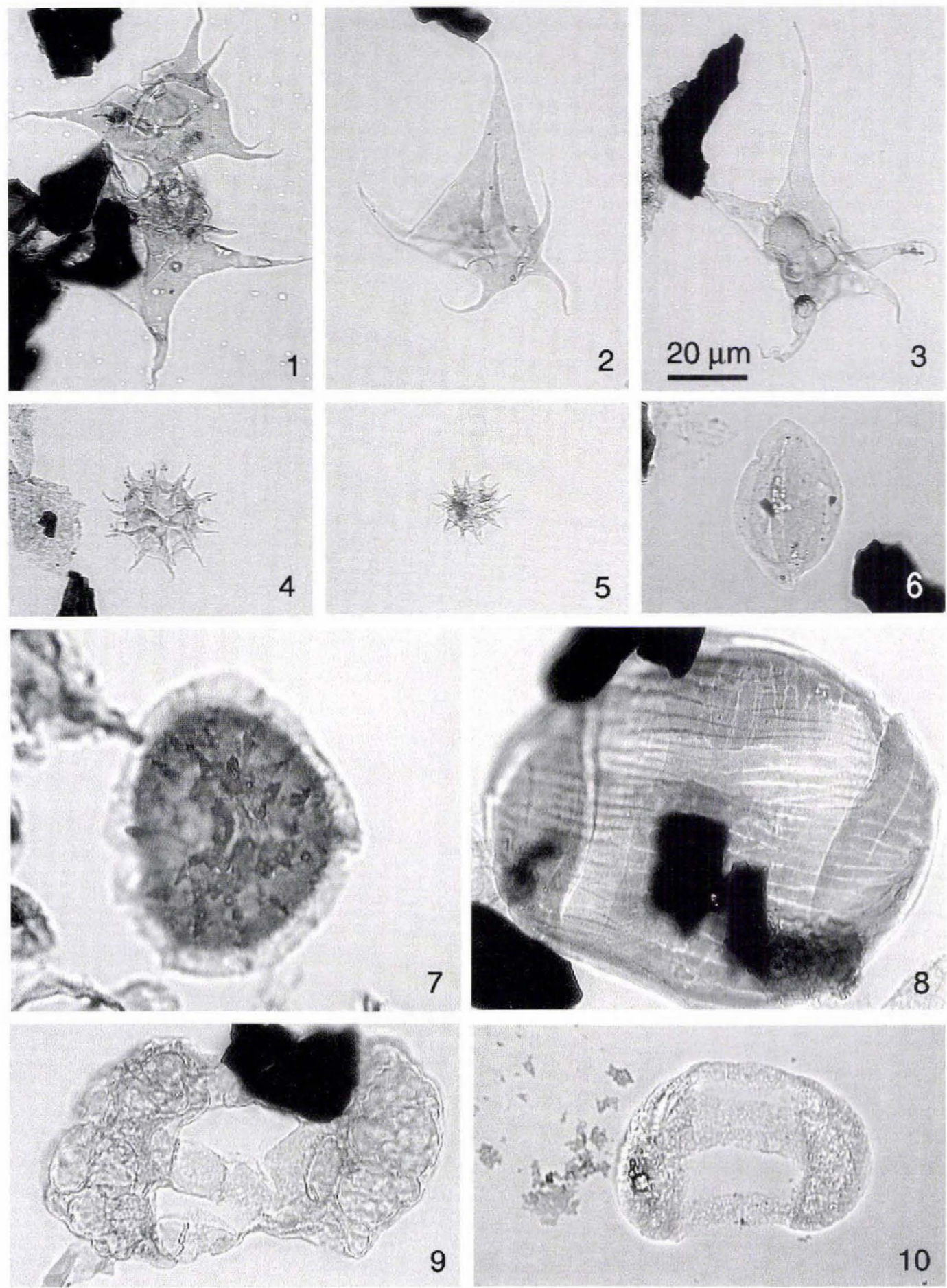

Fig. 8. Palynomorph from the Midnatsfjeld Formation. Fig. 8.1: Unellium starostinum. MGUH 23708 from GGU 361781. Fig. 8.2: Unellium permicum. MGUH 23709 from GGU361781. Fig. 8.3: Unellium sp. (aff. Veryhachium crucitum), MGUH 23710 from GGU 361781. Fig. 8.4: Statostinum reinoddensis, MGUH 23711 from GGU 361781. Fig. 8.5: Michrystridium sp., MGUH 23712 from GGU 361781. Fig. 8.6: Preticolpipollenites sp., MGUH 23713 from GGU 361725. Fig. 8.7: Kraeuselisporites apiculatus, MGUH 23714 from GGU 361781. Fig. 8.8: Vittatina persecta, MGUH 23715 from GGU 361725. Fig. 8.9: Scutasporites sp., MGUH 23716 from GGU 361781. Fig. 8.10: Scutasporites sp. cf. S. unicus, MGUH 23717 from GGU 361725.

N.B.: Figs $8.7-8.10$ are 1.3 times larger than Figs $8.1-8.6$ and the 20 micron bar. 
Fig. 9. Sedimentological log of the upper Moscovian to Gzelian Foldedal Formation in western Foldedal. Location 1 in Fig. 1.

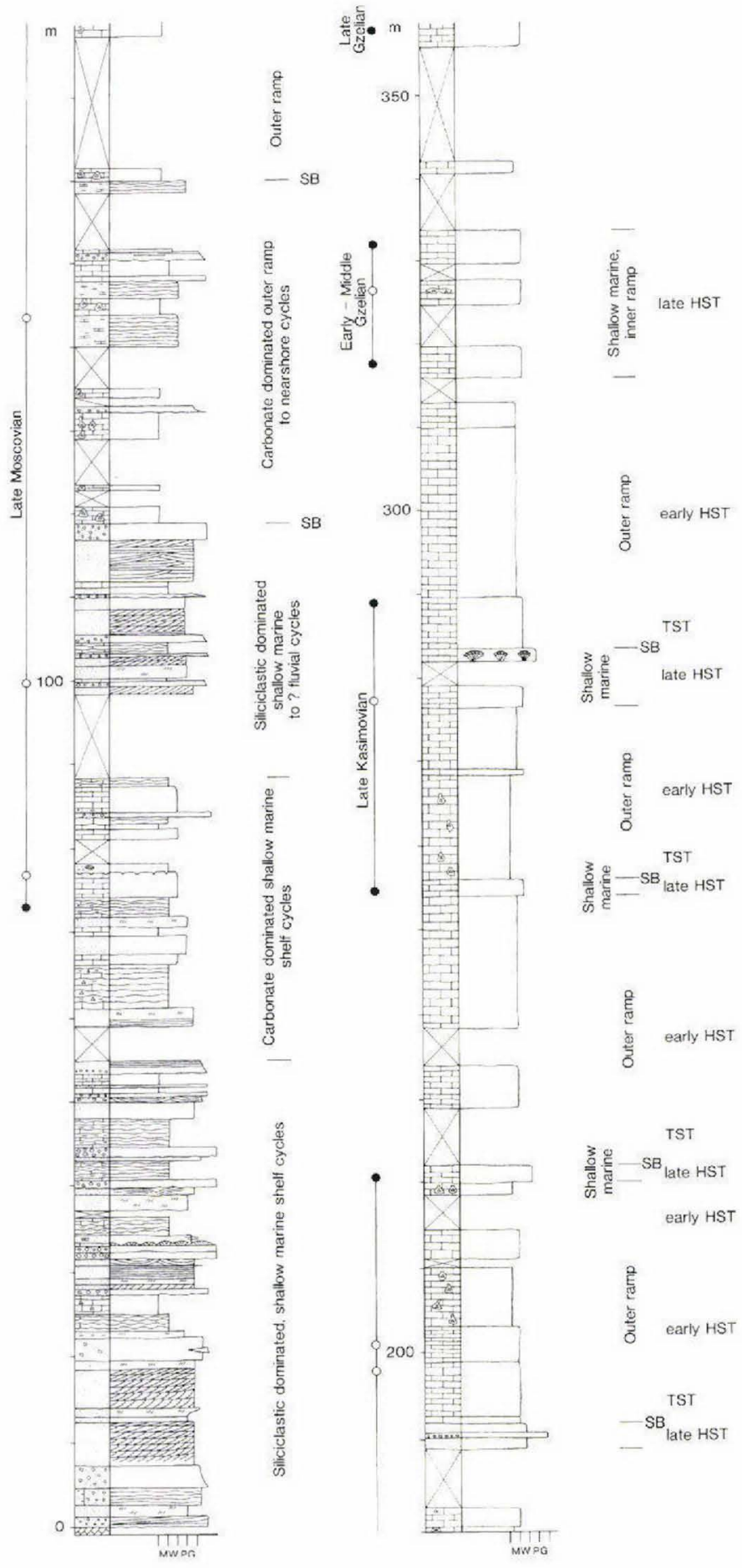

Age. Based on the biostratigraphic evidence presented here, the Foldedal Formation is dated as late MoscovianGzelian. The Kim Fjelde Formation is regarded as being of late Artinskian to late Kungurian age and the Midnat- fjeld Formation most likely is late Kungurian to Kazanian in age (Fig. 2). 


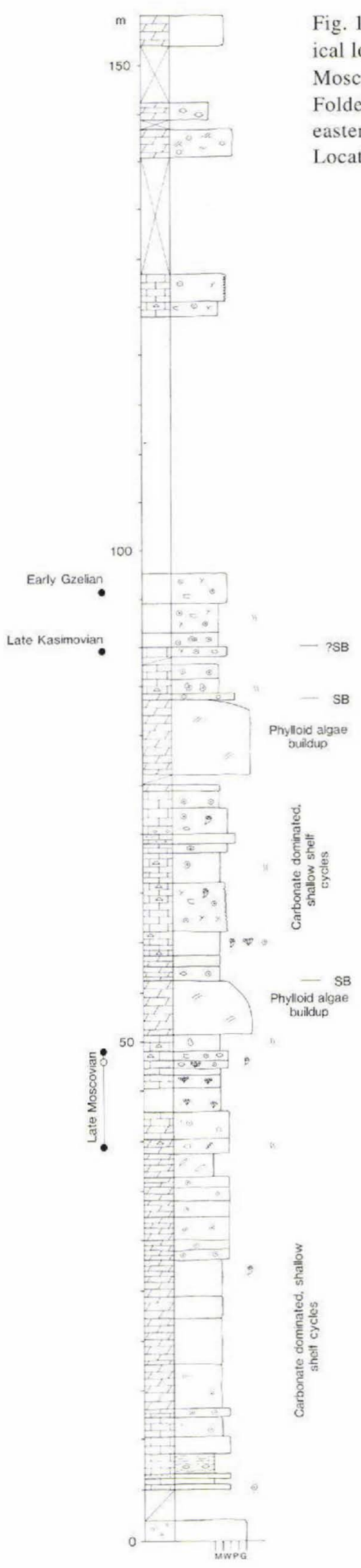

Fig. 10. Sedimentological $\log$ of the upper Moscovian to Gzelian Foldedal Formation in eastern Foldedal. Location 3 in Fig. 1.

\section{Lithostratigraphy}

To keep the lithostratigraphic scheme as simple as possible no new lithostratigraphic units have been erected, but when necessary, the lithostratigraphic units defined by Stemmerik \& Håkansson (1989) have been redefined. In contrast to Håkansson (1979) and Stemmerik \& Håkansson (1989) we prefer to include the Midnatfjeld Formation in the Mallemuk Mountain Group rather than, as originally proposed, the Trolle Land Group. This is due to the conformable relation between the Kim Fjelde and Midnatfjeld formations and the extensive occurrence of carbonates in the upper part of the Midnatfjeld Formation.

\section{Foldedal Formation}

History. This name was originally introduced by Håkansson (1979) for a succession of conglomerates and interbedded sandstones and carbonates which form the base of the Wandel Sea Basin succession around Foldedal in eastern Peary Land. Later, Stemmerik \& Håkansson (1989) also included comparable sequences in Holm Land, Amdrup Land and the Lockwood $\varnothing$ area in the formation. The formation is here defined also to include an Upper Carboniferous succession of shallow shelf carbonates previously assigned to the basal part of the Kim Fjelde Formation.

Type section. The new type section (Fig. 9) is situated on the north side of Foldedal (Locality 1 in Fig. 1) and corresponds to section A in figure 17 of Stemmerik \& Håkansson (1989).

Thickness. Highly variable due to variations in the underlying basement relief and the transgressive nature of the formation. In eastern Peary Land the thickness of the formation ranges from less than $30 \mathrm{~m}$ in the south to more than $450 \mathrm{~m}$ in the Foldedal area in the north.

Lithology. The lower part of the formation consists of interbedded reddish weathering conglomerates, sandstones and biogenic limestones in Peary Land. The siliciclastic sediments become less common upwards, and the upper part of the formation is dominated by shallowing upward cycles of shallow to deeper subtidal carbonates locally with thin tabular carbonate build-ups (Fig. 10) (Stemmerik et al., 1995a).

Boundaries. In eastern Peary Land the formation rests unconformably on a variety of rocks from the North Greenland fold belt (Håkansson, 1979). It is disconformably overlain by Permian sediments of the Kim Fjelde 
Fig. 11. Transition between the Foldedal Formation and Kim Fjelde Formation in the southernmost part of the Wandel Sea Basin in eastern Peary Land. Location 5 in Fig. 1.

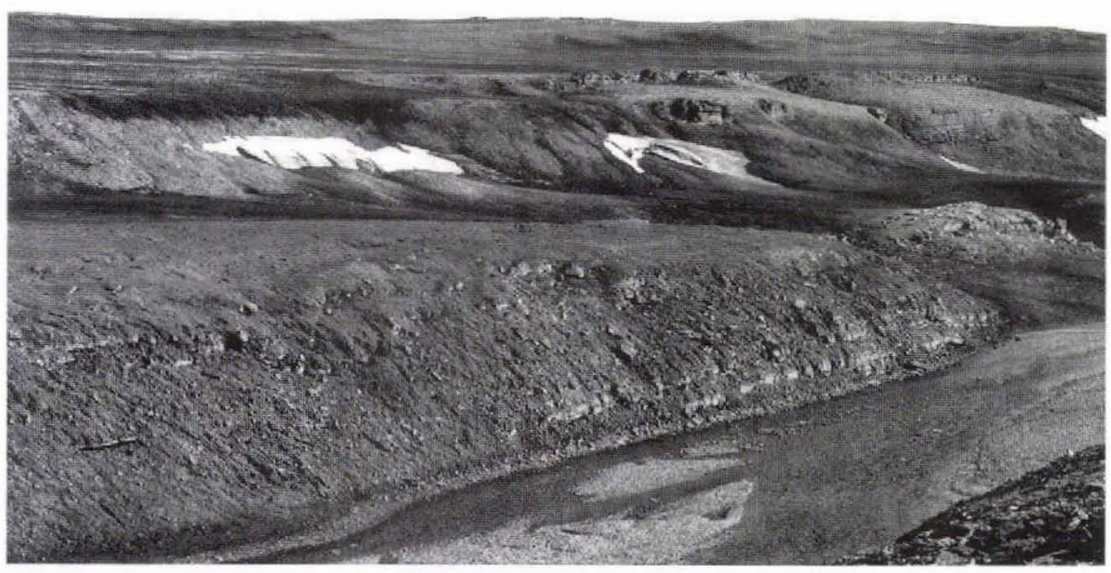

Formation in the southernmost fault block, and here the boundary between the two formations is placed above the uppermost reddish weathering, karstified carbonates (Fig. 11). The boundary is not exposed in Kim Fjelde proper and Foldedal.

Distribution. The formation has a limited distribution in eastern Peary Land around Clarence Wyckoff Bjerg and along Foldedal southwards to locality 4 in Fig. 1.

Age. The formation is of late Moscovian to Gzelian age based on fusulinids with some additional conodont data (Fig. 2). It possibly ranges into the Early Permian.

\section{Kim Fjelde Formation}

History. This name was originally given by Håkansson (1979) to a thick series of marine limestones of proposed Late Carboniferous to Early Permian age found in eastern Peary Land. Later, it was defined to include the Upper Marine Group of Grönwall (1916) in Holm Land and Amdrup Land (Stemmerik \& Håkansson, 1989). The formation is here redefined to include a succession of chertrich carbonates of late Artinskian to Kungurian age. The lowerpart of the formation, as originally defined, is now included in the underlying Foldedal Formation.

Type section. The new type section (Figs 12, 13) is located in northern Foldedal (Locality 2 in Fig. 1) and corresponds to the upper part of section A in figure 20 of Stemmerik \& Håkansson (1989).
Thickness. The formation varies in thickness along the NW-SE striking Trolle Land Fault System, from less than $30 \mathrm{~m}$ in the southwestern Peary Land fault block to more than $380 \mathrm{~m}$ in the north.

Lithology. In northern Kim Fjelde, the formation is composed of well-bedded, chert-rich and biogenic limestones with a fauna dominated by resedimented brachiopods and trepostome bryozoans. Towards the south, these deeper water sediments pass into shallow water biogenic limestones also dominated by brachiopods and trepostome bryozoans, and with abundant Zoophycos. The formation contains minor siliciclastic intervals towards the south.

Boundaries. The lower boundary is a subaerial exposure surface and corresponds to the upper boundary of the Foldedal Formation. The upper boundary is a major flood surface and marks the transition to the dominantly siliciclastic lithologies of the Midnatfjeld Formation.

Age. Late Artinskian to Kungurian based on conodonts, small foraminifera and palynomorphs (Fig. 2). The lower boundary appears diachronous being oldest in the northern part of Kim Fjelde.

\section{Midnatfjeld Formation}

History. This formation was erected by Håkansson (1979) to include siliciclastic sediments of late Permian age in eastern Peary Land. Later fieldwork shows that the formation consists of two shallowing upward megacycles 


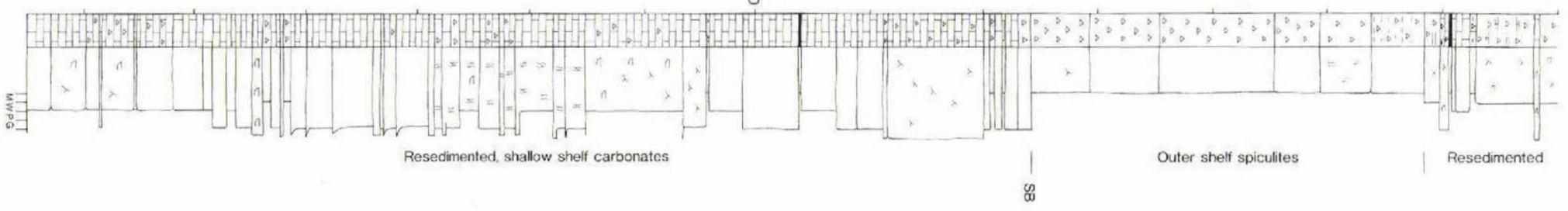

气 Kim Fielde Fm

!

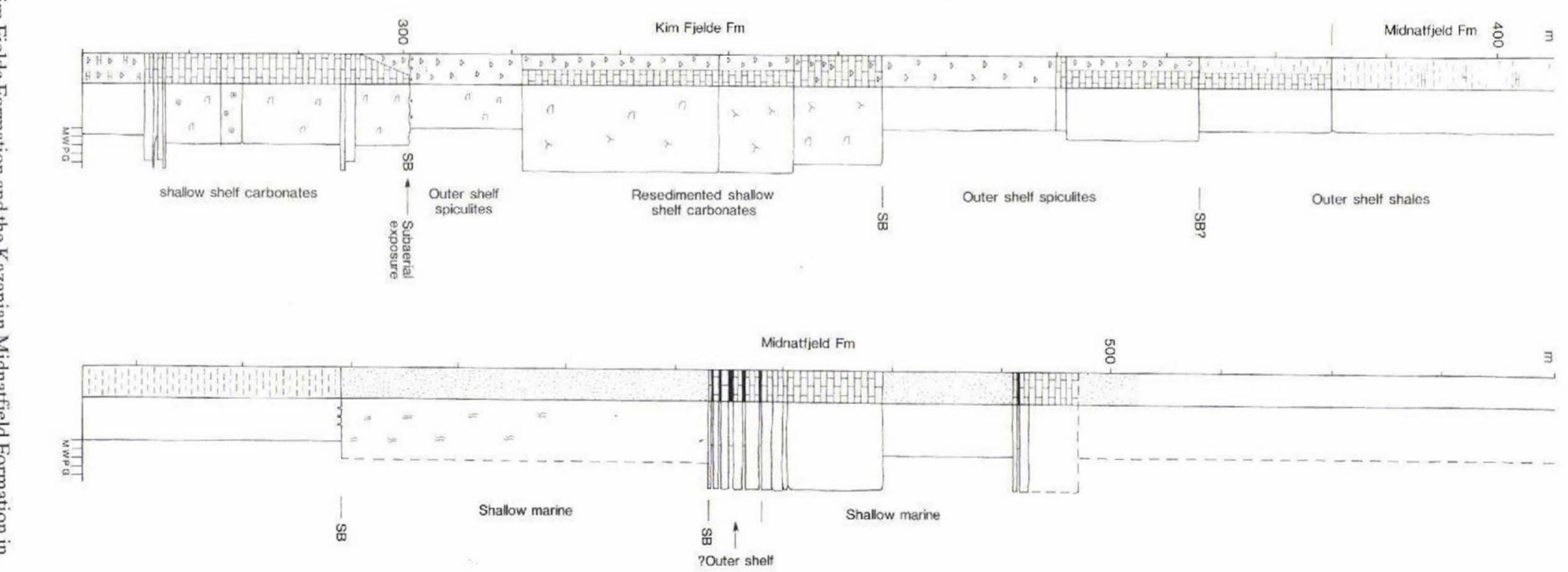


Fig. 13. Kim Fjelde Formation in northern Foldedal. The sediments are dominated by resedimented brachiopod and bryozoan-rich limestones. Note internal disconformities.

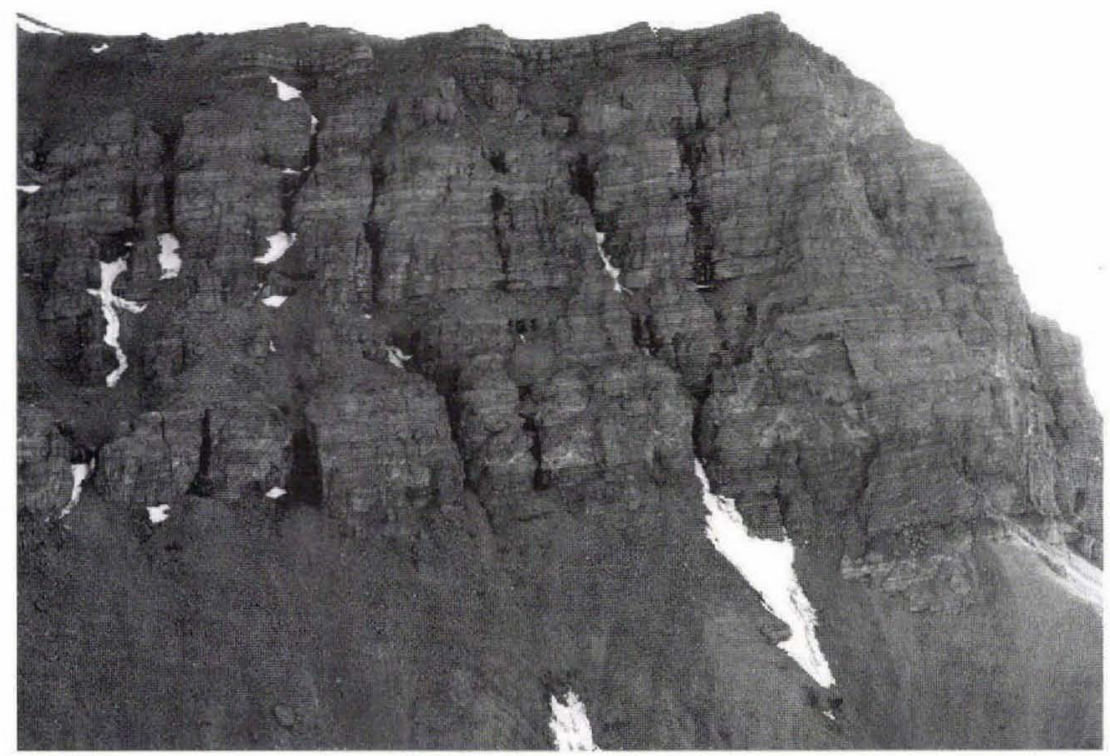

dominated by shales and carbonates in eastern Kim Fjelde and shales and sandstones in northern Kim Fjelde. The abundance of carbonates in the upperpart of the formation, and the conformable relation to the underlying Kim Fjelde Formation led us to include this formation in the Mallemuk Mountain Group.

Type section. The new type section is in northern Foldedal (Fig. 12).

Thickness. The formation is more than $160 \mathrm{~m}$ thick in northern Foldedal and more than $200 \mathrm{~m}$ thick in eastern Kim Fjelde (Fig. 12).

Lithology. The basal part of the formation is composed of laminated and bioturbated shales. These shales pass into a thick succession of bioturbated sandstone in northern Foldedal. In eastern Kim Fjelde the shales pass into bedded biogenic limestones.

Boundaries. The lower boundary is placed at the base of a thick shale unit (Figs 12, 14). It is a major flood surface.
Fig. 14. Bedded chert-rich carbonates of the Kim Fjelde Formation overlain by black laminated shales with slumped carbonates of the Midnatfjeld Formation. The cliff face in the background is composed of bedded limestones of the Midnatfjeld Formation.

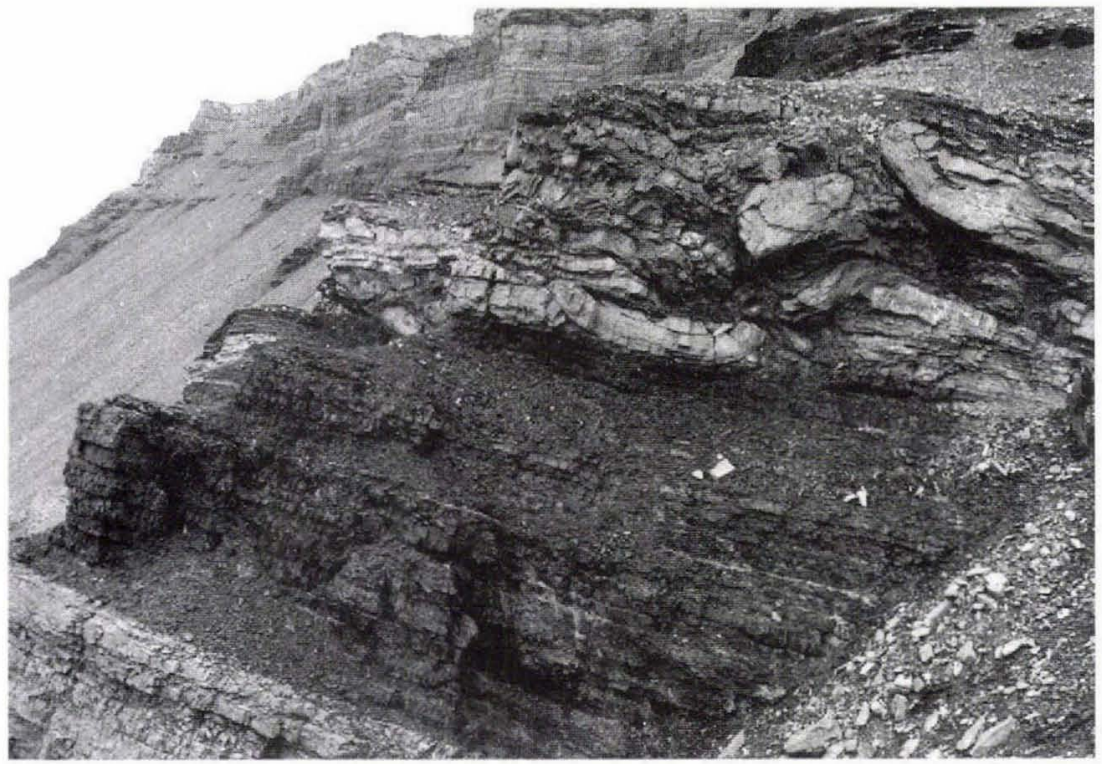




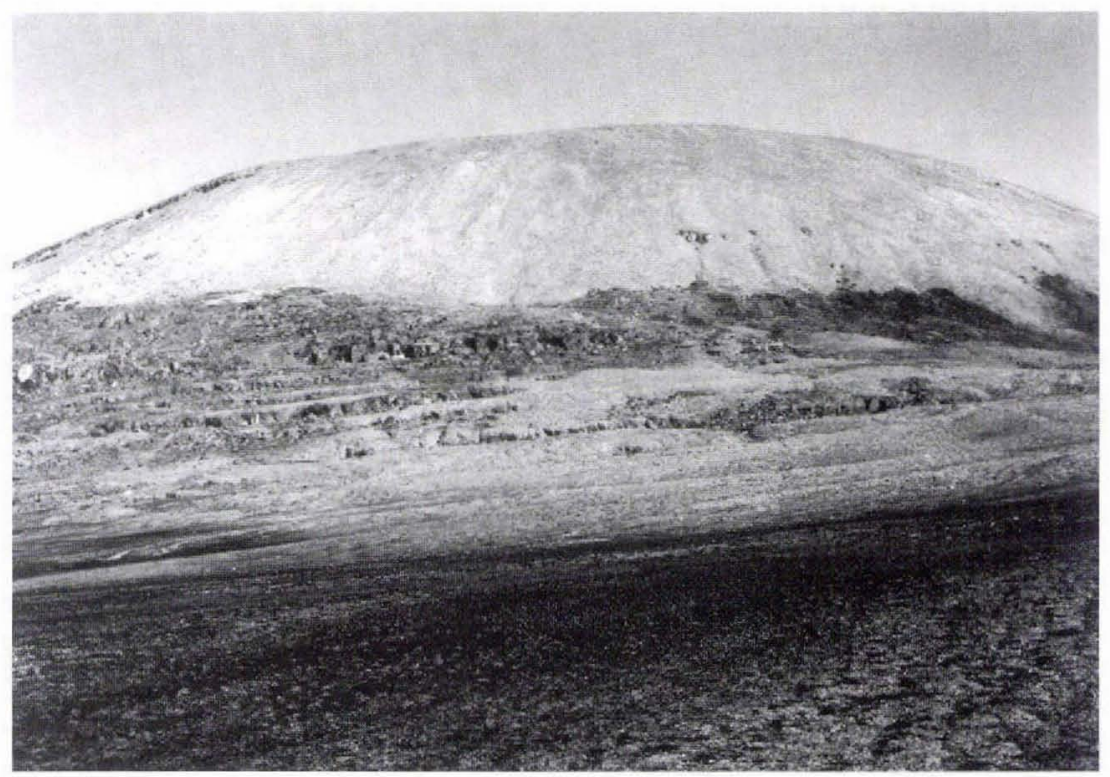

Fig. 15. Karstified Silurian limestone overlain by Moscovian dolomitic limestones. Location 3, eastern Foldedal.
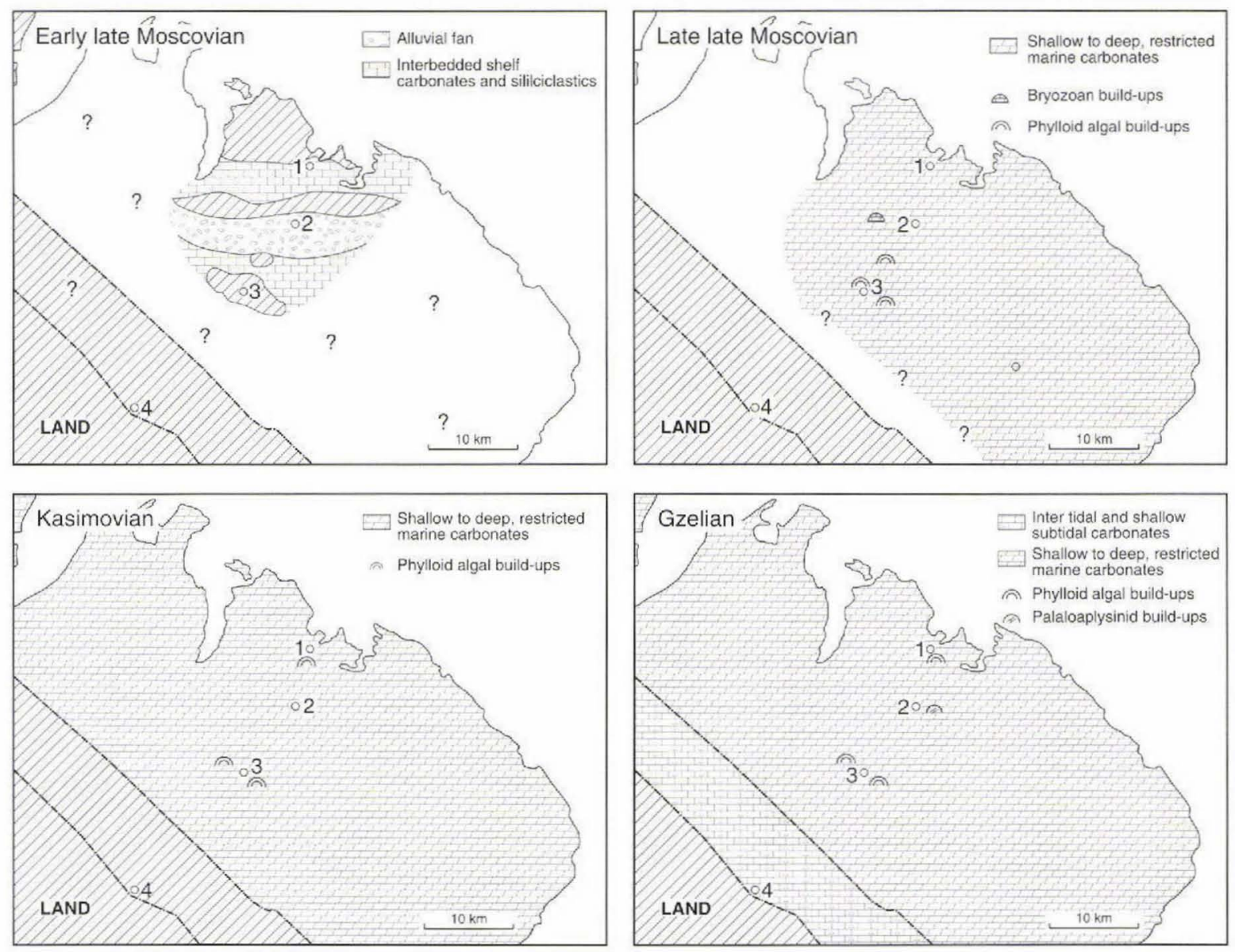

Fig. 16. Palaeogeographic reconstructions of the Foldedal Formation. 
The upper boundary is defined by a low-angle unconformity. In northern Foldedal, the formation is overlain by the Triassic Parish Bjerg Formation and in eastern Kim Fjelde, the formation is overlain by the Parish Bjerg Formation or the Jurassic Ladegårdsåen Formation (Håkansson, 1979).

Age. The formation most likely is of late Kungurian to Kazanian age based on small foraminifera and palynomorphs (Fig. 2).

\section{Depositional evolution}

The sedimentary succession records a number of distinctive depositional phases within the Wandel Sea Basin. These depositional events are controlled by large scale tectonism and overall changes in relative sea level and climate, and they can be correlated with depositional events elsewhere in the Arctic region (e.g. Stemmerik \& Worsley, 1995). During the Upper Palaeozoic, the Wandel Sea Basin shifted northwards as part of the Laurasian plate (Scotese \& McKerrow, 1990). Deposition took place in a warm and semiarid climate during the Moscovian to Sakmarian. The fauna is dominated by foraminifera and algae, and fusulinids are common during this time interval. Evaporites are common locally in theWandel Sea Basin, although very little evidence of evaporite sedimentation is found in eastern Peary Land. During late Artinskian time a marked change in climate occurred throughout the region. This, together with changing palaeohydrographic conditions, probably related to Proto-Atlantic rifting (cf. Stemmerik \& Worsley, 1995) led to deposition in cold temperate water. The fauna is dominated by brachiopods and bryozoans. The continuous northwards migration in combination with an overall climatic cooling towards the end of the Permian (e.g. Beauchamp, 1994) led to even colder depositional conditions during the Kungurian-Kazanian where siliceous sponges became important.

\section{Moscovian}

In eastern Peary Land, Moscovian sediments rest directly on karstified Lower Palaeozoic limestones and Proterozoic sandstones (Fig. 15). The Moscovian sea thus transgressed a highly irregular topography with more than $100 \mathrm{~m}$ of relief in Foldedal, and the entire Foldedal area was not flooded until latest Moscovian - earliest Kasimovian time (Fig. 16). Moscovian deposits are not found on the southernmost fault block and apparently this block marked the southern limit of the depositional basin during the Moscovian (Fig. 16).

The upper Moscovian succession forms one large scale transgressive unit of cyclic shelf deposits. It ranges in thickness from more than $220 \mathrm{~m}$ in the Foldedal- 1 section situated in a palaeogeographic low to less than $90 \mathrm{~m}$ in the Foldedal-3 section measured on a palaeohigh (Figs 9, $10)$.

Early late Moscovian. During early late Moscovian time, siliciclastic material was shed from palaeotopographic highs in western Foldedal into adjacent lows, and thick piles of alluvial conglomerates and interbedded siliciclastics and carbonates were deposited (Figs 9, 16). In a ?fault-controlled subbasin in central Foldedal an approximately $100 \mathrm{~m}$ thick succession of up to $5 \mathrm{~m}$ thick layers of reddish weathering, matrix supported conglomerates forms the basal part of the Moscovian (Fig. 17). These alluvial conglomerates form one large, upward fining unit where individual beds become thinner and more fine-grained upwards. In the lower part of the succession there is evidence of subaerial exposure with karst related cementation.

Further to the north, in the Foldedal-1 section, the basal $20 \mathrm{~m}$ of the Moscovian succession is dominated by

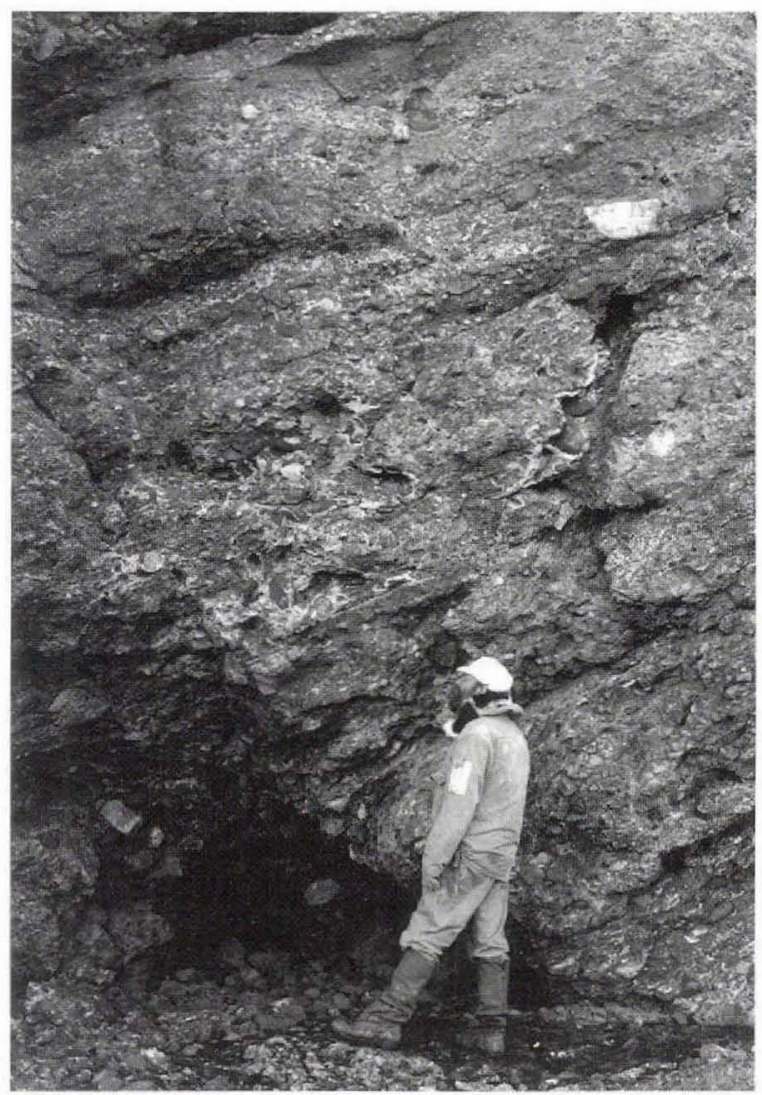

Fig. 17. Alluvial conglomerate with karst-related calcite cement. Lowermost part of Foldedal Formation, southwestern Foldedal. 


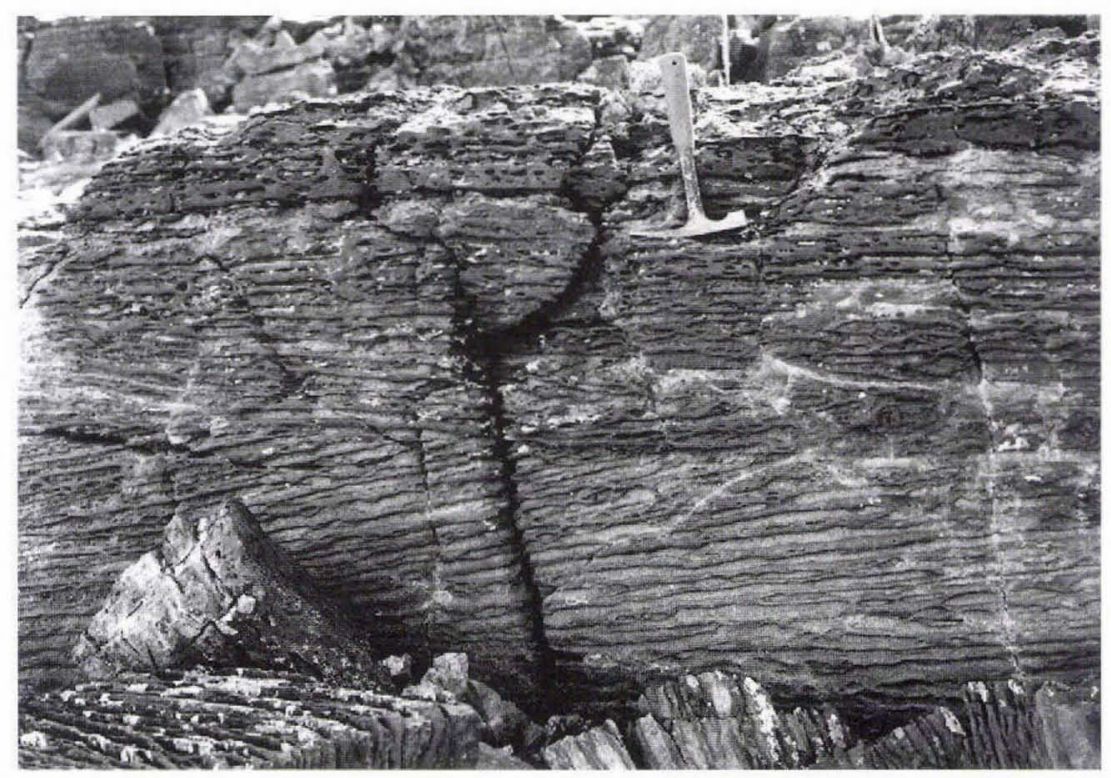

Fig. 18. Cross-bedded sandstone, lower Foldedal Formation, western Foldedal.

interbedded marine conglomerates, planar cross-bedded medium- to coarse-grained sandstones and siltstones (Fig. 14). This siliciclastic unit passes up into a succession of stacked 1-8 $\mathrm{m}$ thick shallowing upward cycles of marine carbonates, cross-bedded sandstone and conglomerates (Figs 9, 18, 19). Deposition took place on a shallow shelf during high frequency fluctuations in sea level. The siliciclastic material was kept in the nearshore areas during sea level rises and fine-grained carbonates were deposited on the shelf. During sea level highstand and falling sea level, siliciclastic shoreline deposits

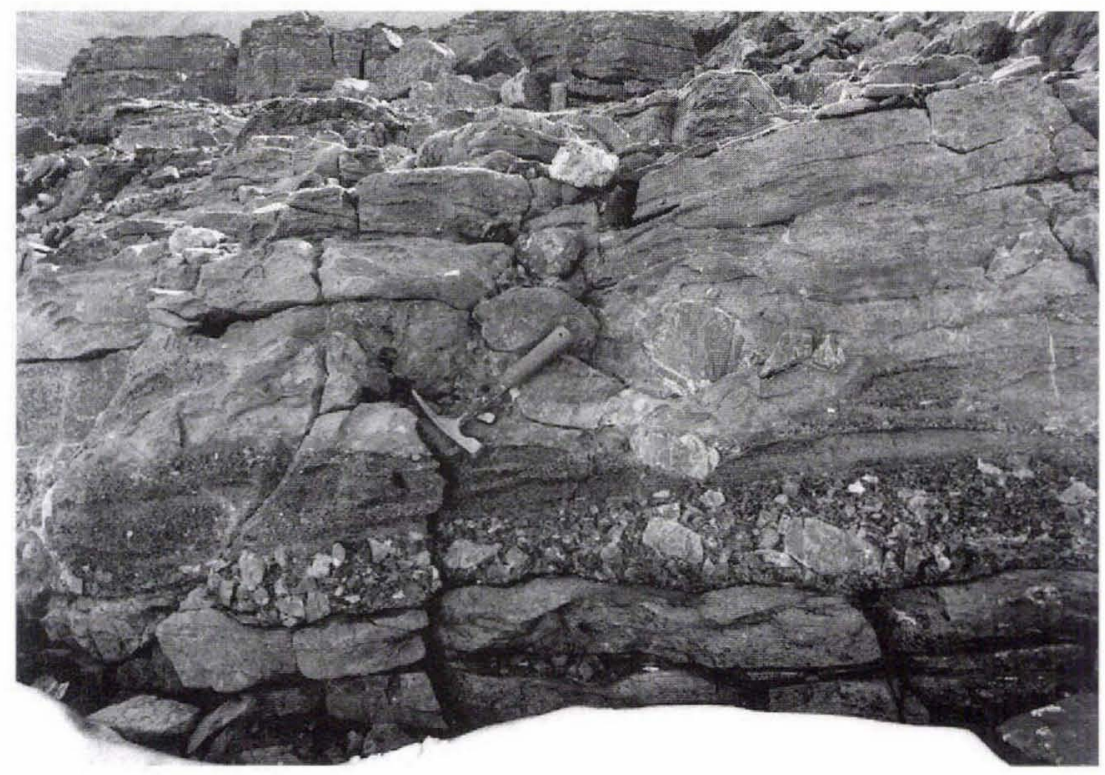

prograded across the shelf and in rare cases, the cycles are terminated by fluvial conglomerates.

Also in this area, the lowermost approximately $100 \mathrm{~m}$ of the upper Moscovian forms an overall transgressive unit. This is reflected in a gradual decrease in the proportion of siliciclastic material within individual cycles and by an upward deepening of the transgressive deposits at the base of individual cycles. Pure carbonate shelf cycles occur in the upper part (Fig. 14).
Fig. 19. Conglomerate overlain by marine limestone. Basal part of Foldedal Formation, western Foldedal. 
Fig. 20. Bioturbated carbonate mudstone, Moscovian part of Foldedal Formation, western Foldedal.

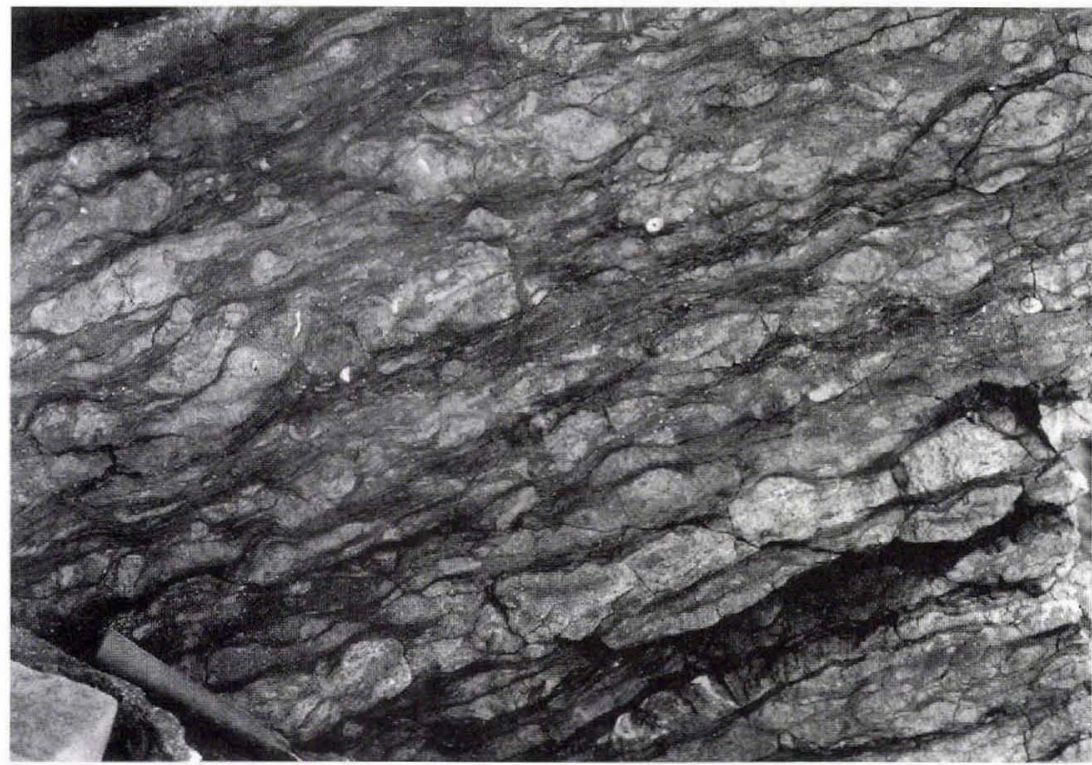

Late late Moscovian. During the middle part of the late Moscovian there was a brief increase in siliciclastic supply in northern Foldedal and approximately $20 \mathrm{~m}$ of cyclic interbedded nearshore sandstones and fluviatile conglomerates were deposited in the Foldedal-1 section (Fig. 14). The remaining part of the late Moscovian was dominated by cyclic shelf carbonates both in the palaeotopographic lows and on the newly transgressed palaeotopographic highs. At this time eastern Peary Land formed a broad carbonate ramp where facies distribution, to some degree, was still controlled by the pre-depositional relief
(Fig. 16). In the palaeogeographic lows, bioturbated carbonate mudstones and wackestones with chert-filled Thalassinoides burrows were deposited during sea level rise (Fig. 20). During sea level highstand and falling sea level foraminifera-dominated grainstones were deposited. These sediments contain a somewhat restricted fauna and were most likely deposited in slightly agitated restricted shelf environments. Above palaeogeographic highs, cyclic interbedded fusulinid-dominated grainstones and dolomitised mudstones with replaced gypsum crystals and nodules were deposited during initial flooding. Later
Fig. 21. Palaeoaplysina boundstone overlain by dolomitic mudstone. Upper Foldedal Formation, northern Foldedal.

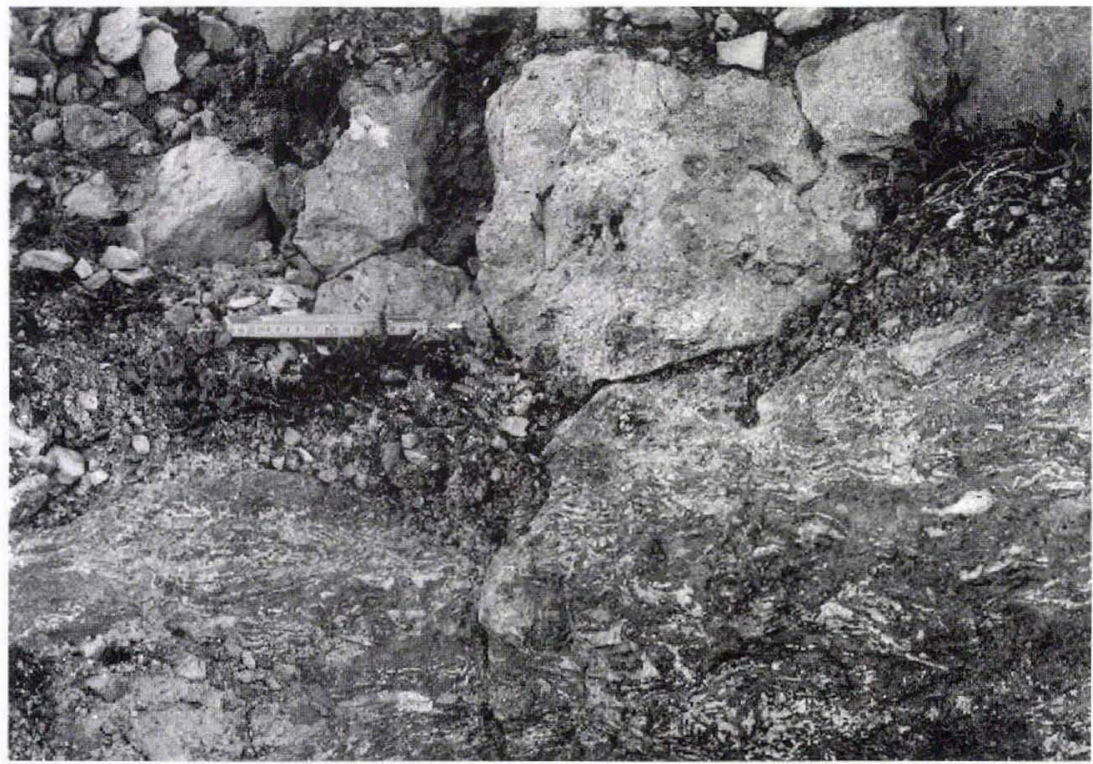




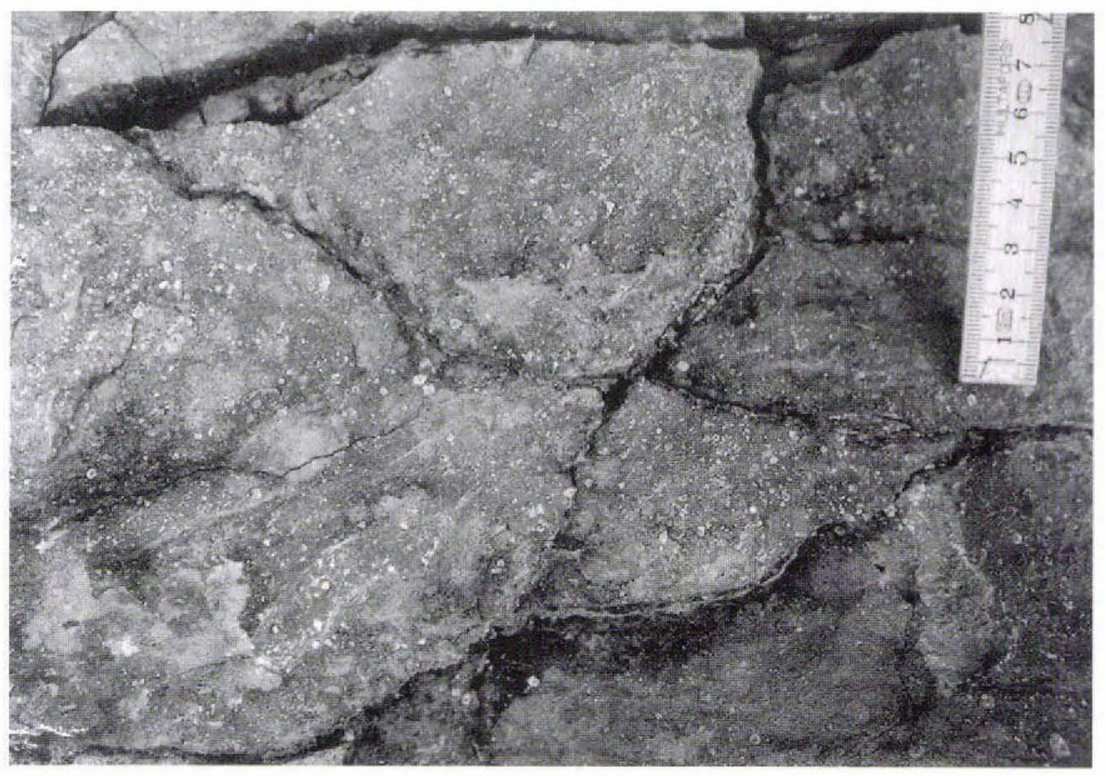

Fig. 22. Crinoid dominated packstone. Gzelian part of Foldedal Formation, location 4 in Fig. 1.

in the late Moscovian, more open marine conditions were established over the highs, and the transgressive part of the cycles became dominated byopen marine packstones with a fauna of crinoids, brachiopods and corals. The highstand deposits are usually completely dolomitised and primary textures can only rarely be identified. Occasionally, the highstand deposits are composed of tabular phylloid algae mounds or bryozoan mounds with abundant early marine cement.

\section{Kasimovian}

The Kasimovian succession ranges in thickness from 25-40 $\mathrm{m}$ above palaeotopographic highs to $85 \mathrm{~m}$ in the palaeotopographic lows. The greater part of the succession belongs to the late Kasimovian Rauserites ex.gr. simplex zone, and early Kasimovian sediments have only rarely been identified.

The Kasimovian succession is composed of $10-30 \mathrm{~m}$ thick upward shoaling cycles with a thick transgressive unit of bioturbated carbonate mudstone and wackestone

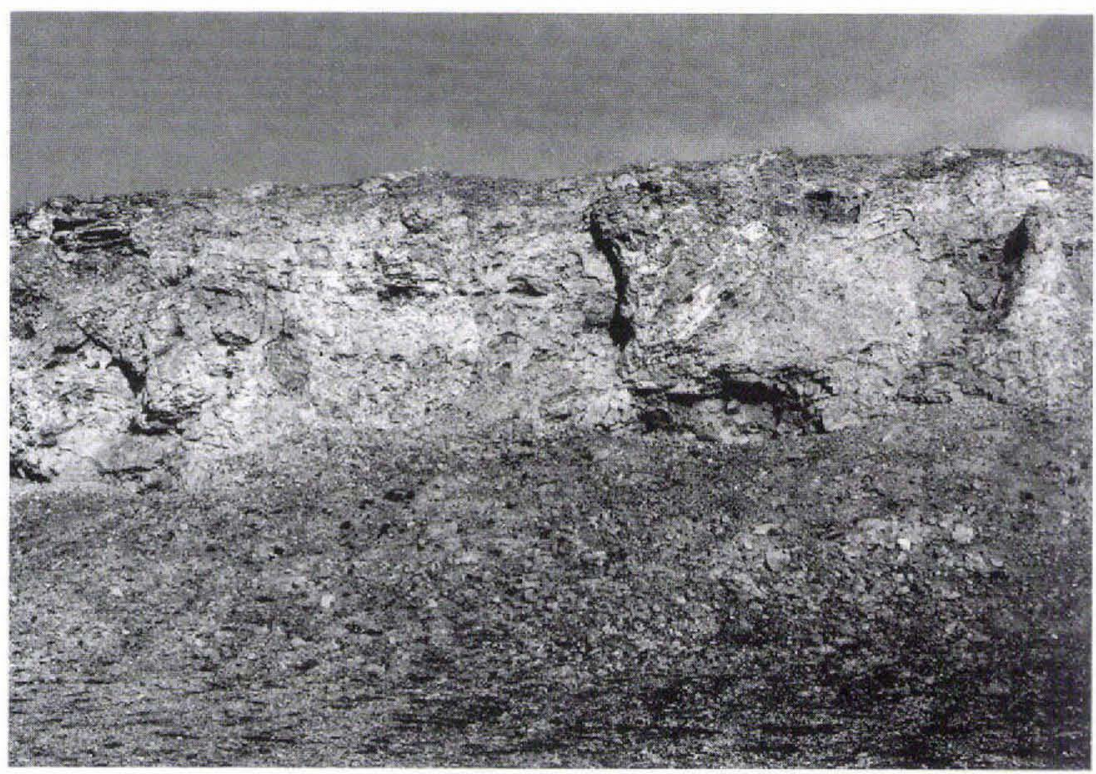

Fig. 23. Karstified upper part of the Foldedal Formation. Location 4 in Fig. 1. 
Fig. 24. Karst breccia in the uppermost part of the Foldedal Formation. Location 4 in Fig. 1.

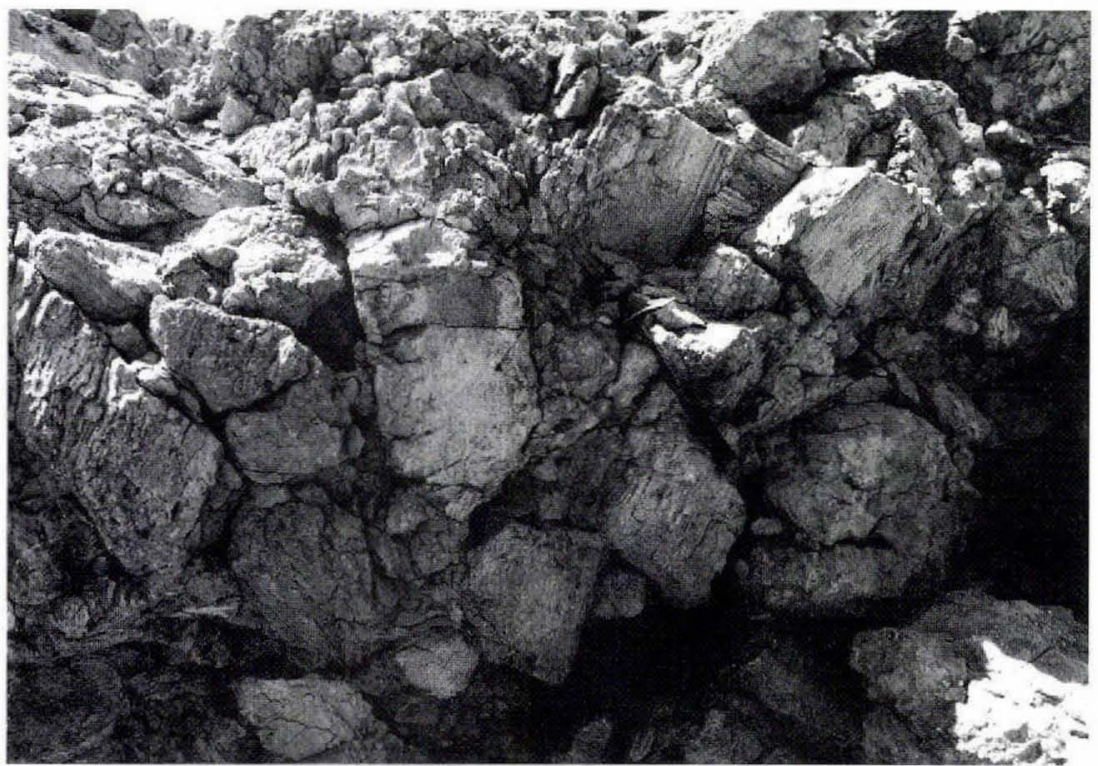

and a thin highstand unit composed of fusulinid-rich packstones (Fig. 14).

The cycles have a much longer duration than the underlying Moscovian cycles and deposition most likely took place on the outer part of a deep carbonate ramp (Fig. 16) (Stemmerik et al., 1995a).

\section{Gzelian}

During Gzelian times the southwestern fault block in the Trolle Land Fault System also became flooded and a broad carbonate shelf was established extending somewhat onto the stable craton. The Gzelian succession ranges in thickness from $30-50 \mathrm{~m}$ and in northern Foldedal it comprises thin shoaling upward cycles of bioturbated wackestones with chert-filled Thalassinoides burrows, biogenic packstones or phylloid algae build-ups. These cycles resemble the underlying Kasimovian cycles, although they are thinner, and most likely they were deposited in an outer ramp setting. Locally in northern Foldedal Palaeoaplysina build-ups occur (Fig. 21). In the newly transgressed areas to the south, the lower part
Fig. 25. Bryozoan dominated rudstone. Kim Fjelde Formation, northern Foldedal.

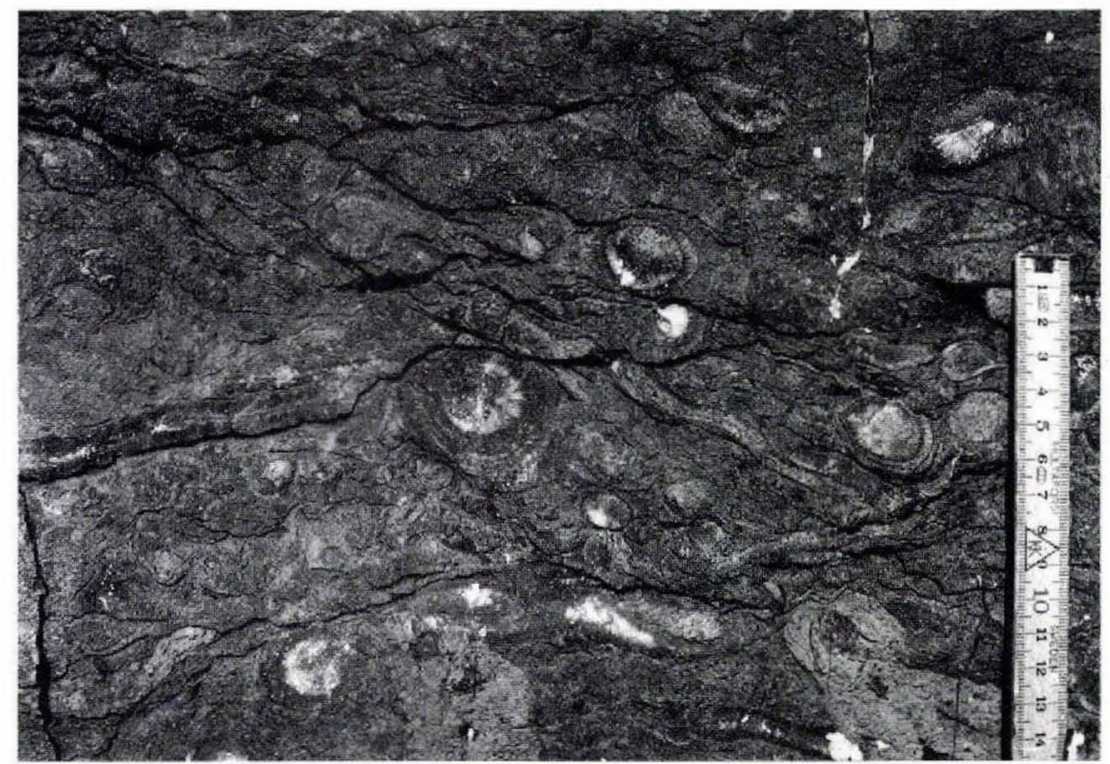




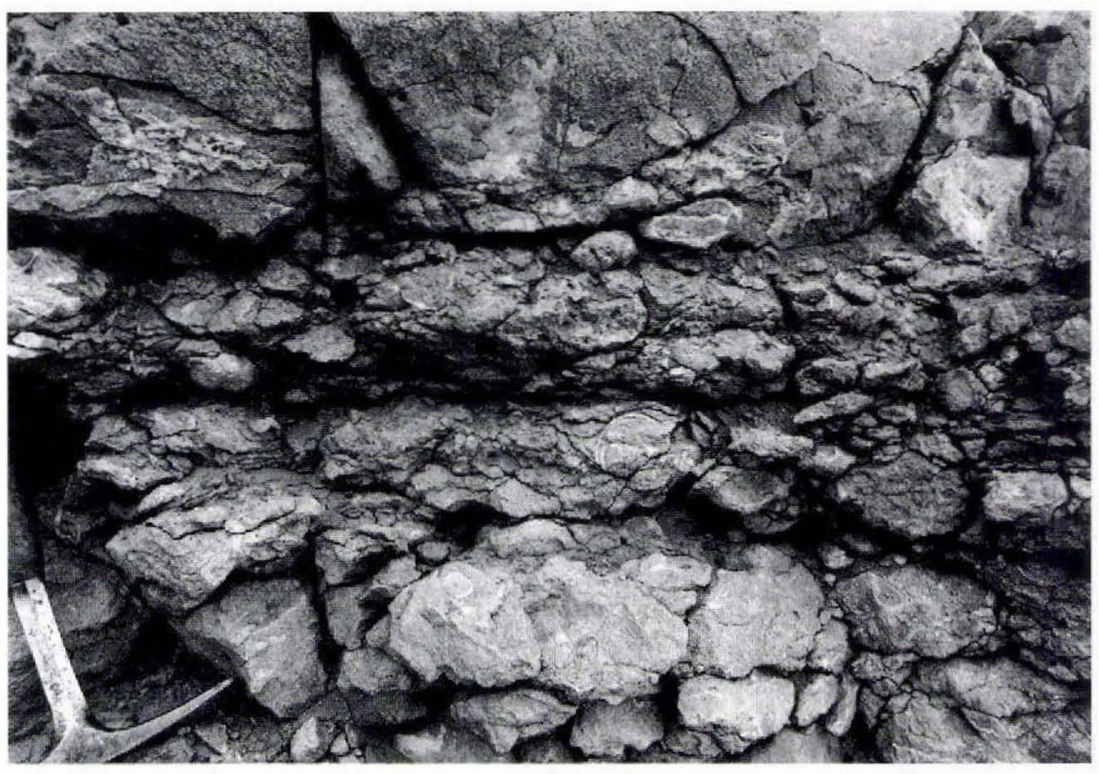

Fig. 26. Brachiopod dominated rudstone. Kim Fjelde Formation, southern Kim Fjelde,
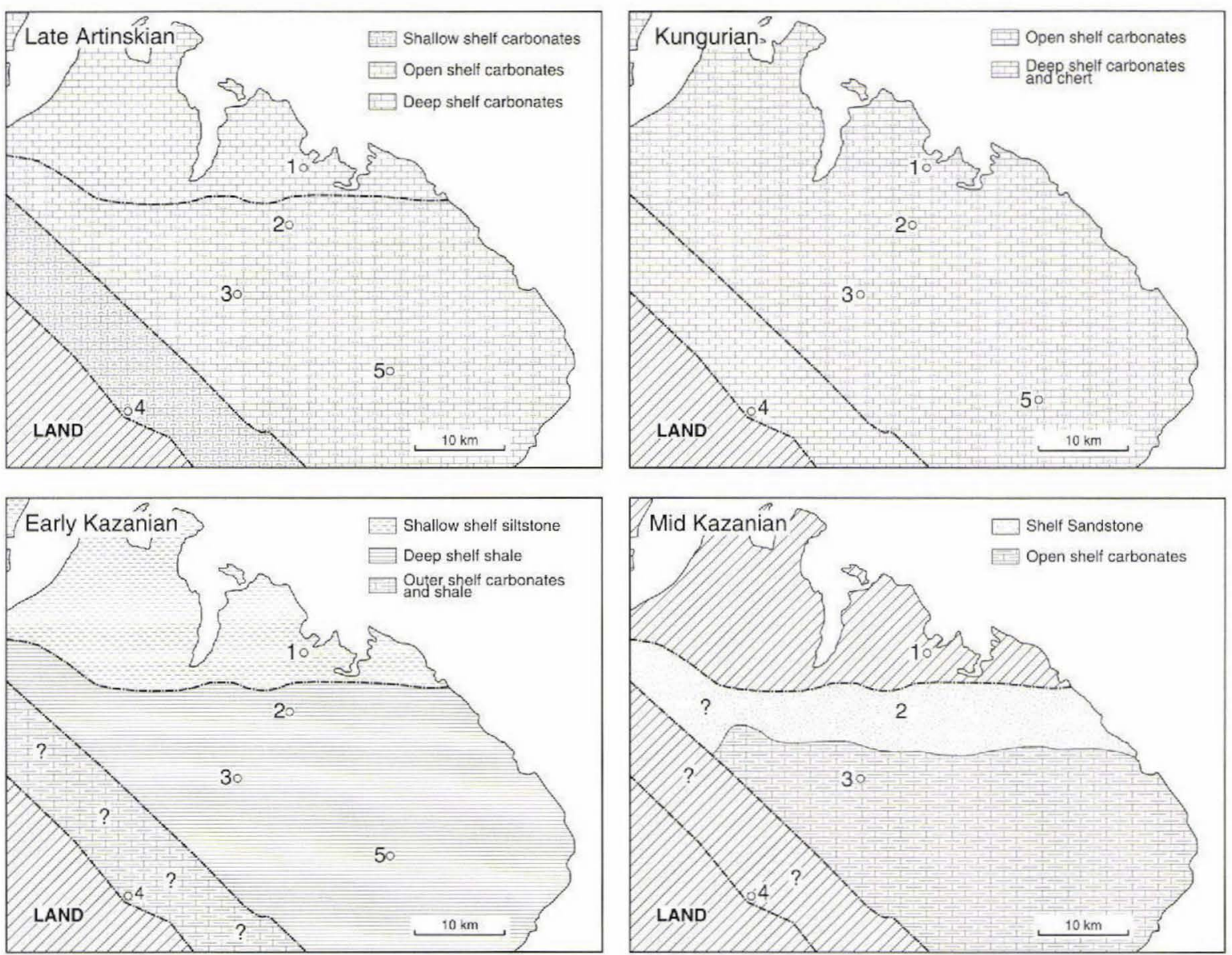

Fig. 27. Palaeogeographic reconstructions of the Kim Fjelde and Midnatfjeld formations. 
of the Gzelian succession is composed of shallow marine, foraminifer-dominated grainstones, packstones and wackestones and sandstones (Fig. 22). The upper part of the succession is karstified and shows evidence of evaporite dissolution, and apparently more restricted marine conditions prevailed in the area during this time interval (Figs 16, 23, 24).

\section{Late Artinskian - Kungurian}

During late Artinskian time eastern Peary Land became flooded again for the first time since the end of the Gzelian. The transition between the Gzelian and late Artinskian sediments is not exposed in the Foldedal area. In the southern part of Kim Fjelde (Locality 4 in Fig. 1), the late Artinskian sea transgressed over a relatively flat karstified surface (Fig. 11).

During late Artinskian, N. pequopensis zone time, only the northern part of the area was flooded. There the succession consists of well-bedded carbonate gravity flows with a fauna of brachiopods and large trepostome bryozoan (Figs 13, 25, 26). The sediments form small, 5-10 m fining upward packages where individual beds become thinner and more fine-grained upwards. These units are often separated by disconformities, and occasionally low relief erosional scoups occur. The sediments in northern Foldedal are most likely turbidites derived from a northern carbonate platform (Fig. 27). Judging from the fauna, the source area was a relatively shallow, well-agitated shelf.

In latest Artinskian time the southwestern fault block in the Trolle Land Fault System became flooded and also this flooding event reached the stable craton. The basal transgressive deposits contain reworked caliche nodules and other clasts of the underlying carbonates (Fig. 28). The overlying sedimentary succession consists of shallow marine carbonate with a fauna dominated by brachiopods and bryozoans, and shallow marine bioturbated sandstones. The sediments resemble the Kim Fjelde Formation on Amdrup Land (Stemmerik \& Håkansson, 1989) and apparently a broad carbonate platform was established along the northern and northeastern margins of the Greenland craton at this time.

In the southern part of the basin, shallow carbonate platform deposition continued into the Kungurian. In northern Peary Land, the sedimentary basin became gradually deeper and during the later parts of the Kungurian, deep water spiculitic chert and shale were deposited over most of eastern Peary Land (Fig. 27).

\section{Kazanian}

The base of the Kazanian is marked by a major flooding event. Deep water conditions prevailed throughout eastern Peary Land, possibly with the exception of the southernmost fault block and an isolated area to the north (Fig. 27). In southern Kim Fjelde, the deepening is associated with tectonically induced slumped carbonate beds (Fig. 14). The Kazanian is composed of two large scale shallowing upwards successions, each more than $100 \mathrm{~m}$ thick. Following initial flooding and deposition of bioturbated and laminated shales, shallow water carbonates started to prograde from the southwestern basin margin into the basin and a thick succession of shallow water,
Fig. 28. Biogenic packstone with reworked caliche nodules, lowermost Kim Fjelde Formation. Location 4 in Fig. 1.

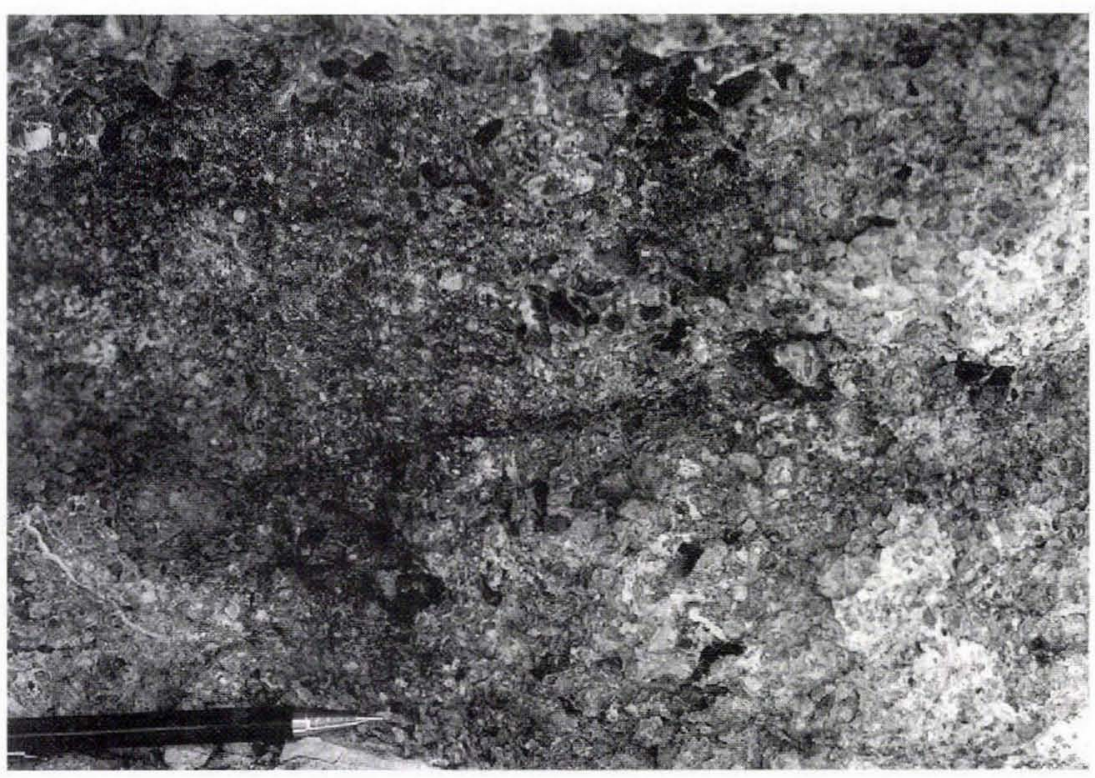




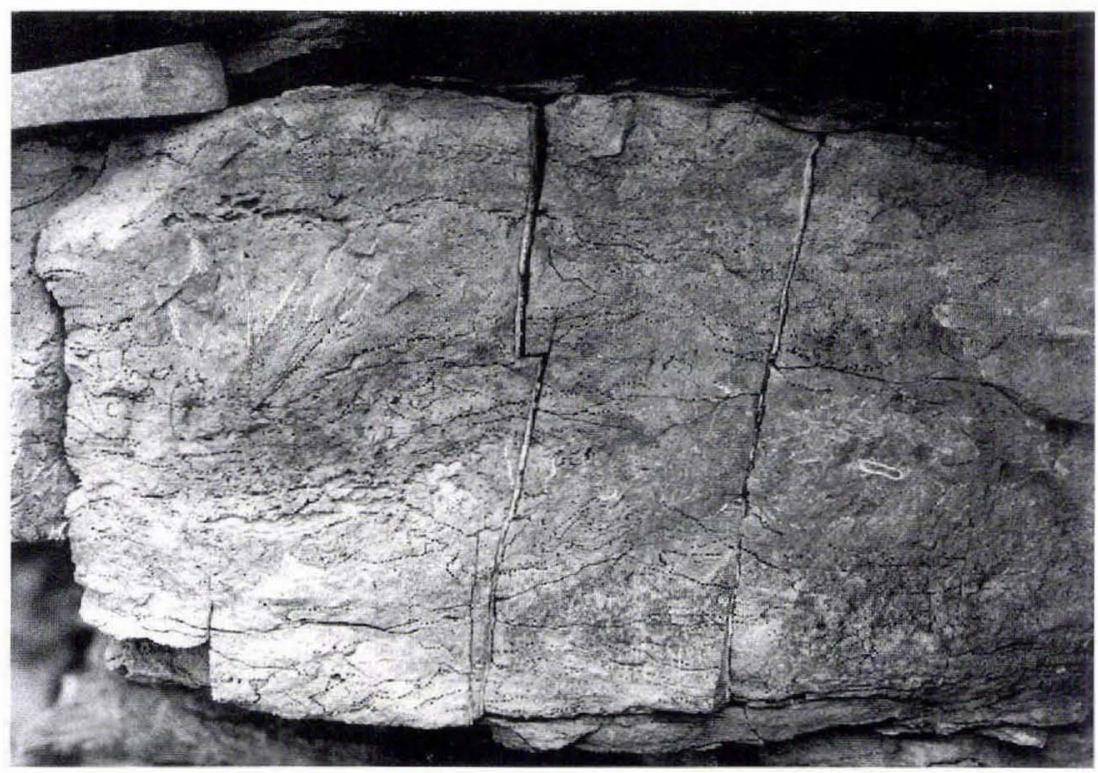

Fig. 29. Bryozoan packstone in the limestone dominated part of the Midnatfjeld Formation. Hammer head for scale, southern Kim Fjelde.

bryozoan and brachiopod dominated carbonates was deposited in southern and eastern Kim Fjelde (Fig. 29). In northern Foldedal a thick succession of bioturbated shelf sandstones was deposited during this time interval. The source for these sandstones was most likely an uplifted area to the northeast (Fig. 27).

During later Kazanian time a new deepening event took place and deeper water shale sedimentation was re-established throughout the area. The final shallowing of the eastern Peary Land part of the basin is marked by renewed progradation of shallow marine carbonates, this time both from the south and the north.

\section{Comparison to adjacent areas}

The marine mid-Carboniferous to Late Permian succession in eastern Peary Land is among the stratigraphically most complete in the Wandel Sea Basin (Fig. 30). The mid-Carboniferous transgression reached Foldedal in northeastern Peary Land in late Moscovian time, slightly later than it reached southern Holm Land and southern Amdrup Land where the basal part of the marine succession is dated as late early Moscovian (Dunbar et al., 1962; Stemmerik \& Håkansson, 1989; Nilsson, 1994). The late Moscovian transgression in eastern Peary Land corresponds in time to the transgression of northern Holm Land and northern Amdrup Land and apparently the Finnmark Platform was also transgressed at this time (Fig. 30; Bugge et al., 1995). Elsewhere in the western Barents Sea, the initial mid-Carboniferous transgression took place during the late Bashkirian, and on Svalbard thick syn-rift successions were deposited prior to the flooding of North Greenland (Fig. 30; Steel \& Worsley, 1984; Stemmerik \& Worsley, 1989; Johannessen \& Steel, 1992).

The overall Moscovian to Gzelian facies development recognised in eastern Peary Land compares with that described from elsewhere in the Wandel Sea Basin and on Spitsbergen and Bjørnøya, although the Moscovian succession in North Greenland is much thicker than the time equivalent successions on Spitsbergen and Bjørnøya (Stemmerik \& Worsley, 1989). In all these areas cyclic shelf deposits were deposited during the late Carboniferous. Throughout the region, the supply of siliciclastic material decreased during the Moscovian, and the Kasimovian and Gzelian successions are dominated by restricted marine carbonate cycles with localised Palaeoaplysina-phylloid algae build-ups (Stemmerik et al., 1994, 1995a; Stemmerik \& Elvebakk, 1994; I. Nilsson, unpublished data).

The early Permian hiatus separating the Foldedal and Kim Fjelde formations in eastern Peary Land also occurs elsewhere in the Wandel Sea Basin (Fig. 30). In eastern Peary Land as well as on Holm Land and Amdrup Land, the hiatus spans the Asselian to mid-Artinskian (Fig. 30). Late Sakmarian deposits have been recognised on Prinsesse Ingeborg Halvø and a local Sakmarian to ?early Artinskian subbasin apparently existed in that area (Håkansson et al., 1989; Nilsson et al., 1991). On Bjørnøya the early Permian hiatus spans the Asselian to mid-Artinskian with the exception of a brief marine incursion during the mid- to late Asselian (Fig. 30). On Spitsbergen 


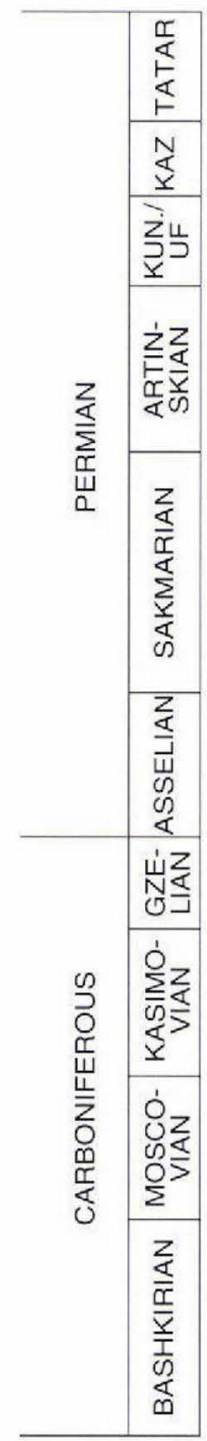

E: Ebbadalen Fm.

$\mathrm{F}$ : Foldedal Fm.

G: Gipsdalen Fm.

$\mathrm{H}$ : Hambergfjellet Fm.

$\mathrm{L}$ : Landnørdingsvika Fm.

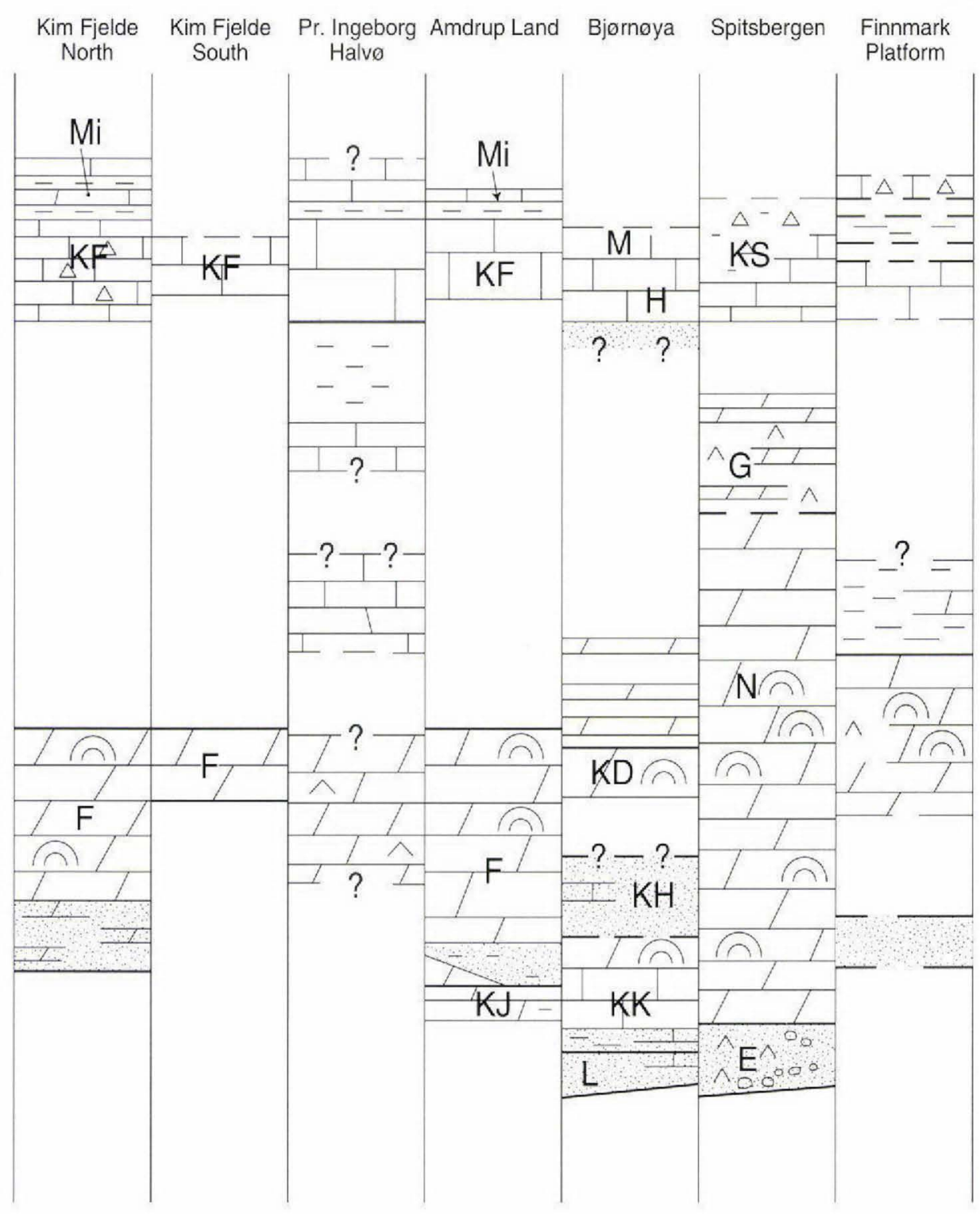

$\mathrm{M}$ : Miseryfjellet Fm.

$\mathrm{N}$ : Nordenskiöldbreen Fm.

KD: Kapp Duner Fm.

KF: Kim Fjelde Fm.

$\mathrm{KH}$ : Kapp Hanna Fm.
$\mathrm{KJ}$ : Kap Jungersen Fm.

KK: Kapp Kåre Fm.

KS: Kapp Starostin Fm.

Mi : Midnatfjeld Fm.

Fig. 30. Correlation of Upper Palaeozoic successions in North Greenland and the Barents Sea area.

and on the Finnmark Platform, sedimentation continued in the Asselian and Sakmarian, and a much shorter late Sakmarian to mid-Artinskian break in sedimentation is present.

The late Artinskian transgression falls within the
N. pequopensis conodont zone and the Schwagerina jenkinsi fusulinid zone throughout the region (Nakrem et al., 1992; Bugge et al., 1995). In most areas, shallow marine limestones similar to those described from the southern part of Peary Land were deposited. The succes- 
sion in northern Kim Fjelde is comparable to sediments deposited in deep basins, like the Nordkapp Basin in the Barents Sea (Stemmerik \& Worsley, 1995). The gradual deepening in the Kim Fjelde area during the late Artinskian and Kungurian has also been recognised on Spitsbergen and elsewhere in the Barents Sea (Stemmerik \& Worsley, 1989, 1995).

The ?earliest Kazanian flooding event that separates the Kim Fjelde Formation from the Midnatfjeld Formation in eastern Peary Land has also been recognised on Amdrup Land (Stemmerik et al., 1995b) and on Prinsesse Ingeborg Halvø (Fig. 30). In the Barents Sea, the Kungurian-Kazanian transition is also marked by a major flooding event and large scale shoaling upwards cycles like those seen in eastern Peary Land occur (e.g. Stemmerik \& Larssen, 1992).

\section{Summary and conclusions}

The Upper Palaeozoic succession in eastern Peary Land is divided into the upper Moscovian to Gzelian Foldedal Formation, the upper Artinskian to Kungurian Kim Fjelde Formation and the upper Kungurian to Kazanian Midnatfjeld Formation. Ages are based on fusulinids in the Foldedal Formation and on a combination of conodonts, small foraminifera and palynomorphs in the Kim Fjelde and Midnatfjeld formations. The succession rests unconformably on Silurian and older rocks. The Foldedal Formation and Kim Fjelde Formation are separated by a major hiatus while the boundary between the Kim Fjelde Formation and the Midnatfjeld Formation is a major, most likely tectonically controlled flood surface.

The large scale depositional pattern seen in eastern Peary Land fits the patterns seen elsewhere in the Arctic region:

The large scale transgressive-regressive pattern seen in the Foldedal Formation is also recognised in Amdrup Land and Holm Land in eastern North Greenland, on Bjørnøya and in the Sverdrup Basin of Arctic Canada.

The early Permian, Asselian to mid-Artinskian hiatus in eastern Peary Land corresponds to a hiatus on Holm Land and Amdrup Land in eastern North Greenland and on Bjørnøya. Elsewhere in the Arctic region, Asselian and Sakmarian deposits are widespread, and apparently the hiatus in eastern Peary Land is related to tectonic inversion of this area. Time equivalent tectonic inversion is also seen in Amdrup Land and Holm Land and on Bjørnøya.

The late Artinskian transgression at the base of the Kim Fjelde Formation corresponds to a major transgres- sion throughout the Arctic region. This event is related to major tilting in the Sverdrup Basin and in the western Barents Sea (Beauchamp, 1993; Johansen et al ., 1994), and judging from the facies patterns this transgression is also related to tectonic tilting in eastern Peary Land.

The ?early Kazanian flooding event at the base of the Midnatfjeld Formation is associated with major slumping and is most likely associated with renewed tectonism in the area. The Kazanian succession is composed of two large scale transgressive-regressive units. Similar large scale transgressive-regressive units occur in the Barents Sea.

\section{References}

Baesemann, J. F. 1973: Missourian (Upper Pensylvanian) conodonts of northeastern Kansas. J. Paleontology 47, 689-710.

Baryshnikov, V. V., Zolotova, V. P. \& Koscheleva, V. F. 1982: [New species of foraminifers from the Artinskian stage of the Pre-Ural of Perm.] Akademiia Nauk SSSR, Ural'ski Nauchnii Tsentr. Institut Geologii i Geokhimii, Sverdlovsk, Nauchnye Doklady, 3-54. (In Russian.)

Beauchamp, B. 1993: Carboniferous and Permian reefs of the Sverdrup Basin, Canadian Arctic: an aid to Barents Sea exploration. In Vorren, T. O., Bergsager, E., Dahl-Stamnes, $\varnothing$. A., Holter, E., Johansen, B., Lie, E. \& Lund, T. B. (ed.) Arctic Geology and Petroleum Potential. Norwegian Petrol. Soc. Spec. Publ. 2, 217-241.

Beauchamp, B. 1994: Permian climatic cooling in the Canadian Arctic. In Klein, G. D. (ed.) Pangea: paleoclimate, tectonics and sedimentology during accretion, zenith and breakup of a supercontinent. Geol. Soc. Amer. Spec. Pap. 228, 229-245.

Beauchamp, B. \& Henderson, C. M. 1994: The Lower Permian Raanes, Great Bear Cape and Trappers Cove formations, Sverdrup Basin, Canadian Arctic: stratigraphy and conodont zonation. Bull. geol. Surv. Canada, 42, 562-597.

Beauchamp, B., Harrison, J. C. \& Henderson, C. M. 1989: Upper Paleozoic stratigraphy and basin analysis of the Sverdrup Basin, Canadian Arctic Archipelago: Part 2, Transgressiveregressive sequences. Pap. geol. Surv. Canada 89-1G, 105-113.

van den Boogaard, M. \& Bless, M. J. M. 1985: Some conodont faunas from Aegiranum marine band. Pal. Proceed. Ser. B 8, $133-154$.

Bugge, T., Mangerud, G., Elvebakk, G., Mørk, A., Nilsson, I., Fanavoll, S. \& Vigran, J. O. 1995: The Upper Palaeozoic succession on the Finnmark Platform, Barents Sea. Norsk geol. Tidsskr. 75, 3-30.

Dunbar, C. P., Troelsen, J., Ross, C., Ross, J. P. \& Norford, B. 1962: Faunas and correlation of the Late Paleozoic rocks of northeast Greenland. Meddr Grønland 167(4), 16 pp.

Dunn, D. L. 1966: New pennsylvanian conodonts from southwestern United States. J. Paleontology 40, 1294-1303.

Grayson, R. C., Merill, G. K. \& Lambert, L. L. 1990: Carboniferous gnathodontid conodont apparatuses: evidence of a dual origin for Pennsylvanian taxa. Courier Forschunginstitut Senckenberg 118, 353-396. 
Grönwall, K. G. 1916: The marine Carboniferous of North-East Greenland and its brachiopod fauna. Meddr Gronland $\mathbf{4 3}$ (20), $110 \mathrm{pp}$.

Håkansson, E. 1979: Carboniferous to Tertiary development of the Wandel Sea Basin, eastern North Greenland. Rapp. Grønlands geol. Unders. 85, 11-15.

Håkansson, E. \& Stemmerik, L. 1984: Wandel Sea Basin - the North Greenland equivalent to Svalbard and the Barents Shelf. In Spencer, A. M. et al. (ed.) Petroleum geology of the North European margin. 97-107, London: Graham \& Trotman (for Norwegian Petroleum Society).

Håkansson, E., Madsen, L. \& Pedersen, S. A. S. 1989: Geological investigations of Prinsesse Ingeborg Halv $\emptyset$, eastern North Greenland. Rapp. Gronlands geol. Unders. 145, 113-118.

Johannessen, E. P. \& Steel, R. J. 1992: Mid-Carboniferous extension and rift-infill sequence in the Billefjorden Trough, Svalbard. Norsk geol. Tidsskr. 72, 35-48.

Johansen, S. E., Gudlaugsson, S. T., Svånå, T. A. \& Faleide, J. I. 1994: Late Palaeozoic evolution of the Loppa High, Barents Sea. In Johansen, S. E. (ed.) Geological evolution of the Barents Sea with special emphasis on the late Palaeozoic development. Unpublished Dr.Science Thesis, Univ. Oslo, 49 pp.

Konieczny, R. M. 1987: Permian palynostratigraphy of Svalbard. Confidential Report. Inst. KontinentalsokkelUnders. Sintefgruppen, 1-194. (Unpublished.)

Kozitskaya, R. I. 1983: [Conodonts in the Upper Carboniferous sediments of Dneprovsko-Donetzkaya depression.] Izv. Akad. Nauk. SSSR, Ser. Geol. 11, 69-76. (In Russian)

Mangerud, G. 1994: Palynological assemblages from the Permian and lowermost Triassic succession on the Finnmark Platform, Barents Sea. Rev. Palaeobot. Palynol. 82, 317-349.

Mangerud, G. \& Konieczny, R. M. 1993: Palynology of the Permian succession of Spitsbergen, Svalbard. Polar Research 9(2), 155-167.

Nakrem, H. A. 1991: Conodonts from the Permian succession of Bjørnøya (Svalbard). Norsk geol. Tidsskr. 71, 235-248.

Nakrem, H. A., Nilsson, I. \& Mangerud, G. 1992: Permian biostratigraphy of Svalbard (Arctic Norway) - A review. Intern. Geol. Rev. 34(9), 933-959.

Nilsson, I. 1994: Upper Palaeozoic fusulinid assemblages, Wandel Sea Basin, North Greenland. Rapp. Grønlands geol. Unders. 161, 45-71.

Nilsson, I., Håkansson, E., Madsen, L., Pedersen, S. A. S. \& Stemmerik, L. 1991: Stratigraphic significance of new fusulinid samples from the Upper Palaeozoic Mallemuk Mountain Group, North Greenland. Rapp. Gronlands geol. Unders. 150, 29-32.

Petryk, A. A. 1977: Upper Carboniferous (Late Pennsylvanian) microfossils from the Wandel Sea Basin, eastern North Greenland. Rapp. Grønlands geol. Unders. 85, 16-21.

Pronina, G.P. 1990: [Stratigraphic significance of small foraminifers from Late Permian of Transcaucasia.] Vsesoyuznyi Ordena Lenina Nauchno-issledovatel'skii, Geologicheskii Institut, Leningrad, 1-22. (In Russian.)

Scotese, C. R. \& McKerrow, W. S. 1990: Revised world maps and introduction. In McKerrow, W. S. \& Scotese, C. R. (ed.) Palaeozoic palaeogeography and biogeography. Geol. Soc. London. Mem. 12, 1-21.
Sosipatrova, G. P. 1967: [Upper Paleozoic foraminifera of Spitsbergen.] In Sokolev, V. N. \& Vasilevskaja, N. (ed.) Stratigraphy of Spitsbergen. Leningrad: NIIGA (In Russian.) English version: British Library, Lending Division, Boston Spa. (1977; 125-163).

Steel, R.J. \& Worsley, D. 1984: Svalbard's post-Caledonian strata. An atlas of sedimentational patterns and palaeogeographic evolution. In Spencer, A. M. et al. (ed.). Petroleum Geology of the North European Margin, 109-135. Graham \& Trotman for Norwegian Petroleum Society.

Stemmerik, L. \& Elvebakk, G. 1994: A newly discovered midCarboniferous - ?early Permian reef complex in the Wandel Sea Basin, eastern North Greenland. Rapp. Gronlands geol. Unders. 161, 39-44.

Stemmerik, L. \& Håkansson, E. 1989: Stratigraphy and depositional history of the Upper Palaeozoic and Triassic sediments in the Wandel Sea Basin, central and eastern North Greenland. Rapp. Grønlands geol. Unders. 143, 21-45.

Stemmerik, L. \& Håkansson, E. 1991: Carboniferous and Permian history of the Wandel Sea Basin, North Greenland, Bull. Grønlands geol. Unders. 160, 141-151.

Stemmerik, L. \& Larssen, G. B. 1992: Upper Palaeozoic geology in the Barents Sea and adjacent areas: Upper Palaeozoic carbonate studies in the Loppa High - Stappen High area, western Barents Sea. Inst. KontinentalsokkelUnders. Report 23.1438.00/08/92. Reg.no. 92.155. (Unpublished.)

Stemmerik, L. \& Worsley, D. 1989: Late Palaeozoic sequence correlations, North Greenland, Svalbard and the Barents Shelf. In Collinson, J. D. (ed.) Correlation in hydrocarbon exploration, 99-111. Graham \& Trotman for Norwegian Petroleum Society.

Stemmerik, L. \& Worsley, D. 1995: Permian history of the Barents Shelf area. In Scholle, P. A., Peryt, T. M. \& UlmerScholle, D. S. (ed.) The Permian of northern Pangea 2: Sedimentary basins and economic resources. Berlin: Springer Verlag, 81-97.

Stemmerik, L., Larson, P. A., Larssen, G. B., Mørk, A. \& Simonsen, B. T. 1994: Depositional evolution of Lower Permian Palaeoaplysina build-ups, Kapp Duner Formation, Bjørnøya, Arctic Norway. Sedimentary Geology 92, 161-174.

Stemmerik, L., Nilsson, I. \& Elvebakk, G. 1995a: Gzelian-Asselian depositional sequences in the western Barents Sea and North Greenland. In Steel, R. et al. (ed.) Sequence stratigraphy on the Northwest European margin. Norwegian Petroleum Society, Special Publication 5, 529-544.

Stemmerik, L., Dalhoff, F. \& Nilsson, I. 1995b: Petroleum geology and thermal maturity of eastern North Greenland - a new petroleum energy research project. Rapp. Grønlands geol. Unders. 165, 49-52.

Xia G.\& Zhang Z. 1984: Foraminifera. In Tianjin Institute of Geology and Mineral Resources (ed.) Paleontological Atlas of North China. III. Micropaleontological Volume. (In Chinese) Beijing: Geological Publishing House, 5-59, 726-736. 